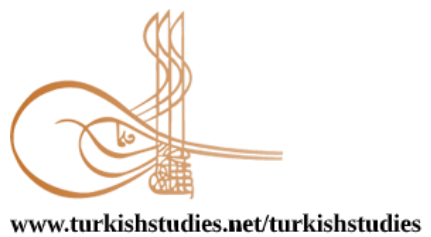

Turkish Studies

www.turkishstudies.net/turkishstudies

eISSN: $1308-2140$

BALKAN
UNIVERSITY

Sponsored by IBU

Research Article / Araştırma Makalesi

\title{
Kitlesel Göçler ve Enfeksiyon Hastalıkları Arasındaki İlişkiler Kapsamında Antropolojik Değerlendirmeler: Koronavirüs (Covid-19)
}

\author{
Anthropological Evaluations in the Context of Mass Migration and Infectious Diseases: \\ Coronavirus (Covid-19)
}

Damla Taşkın* - Vahdet Özkoçak ${ }^{* *}$

\begin{abstract}
Political, social, health, economic, administrative and military management decisions of states have been effective in shaping human history. In addition, secondary causes such as natural disasters, geographical conditions and modern technology have affected humanity and caused a series of chain events. The aim of our study is war and mass migrations; human history and societies with a series of chain events; socio-cultural, economic, legal, governmental styles and community (public) health have profoundly affected and changed areas. In this study, cause-effect relationship will be examined in the context of epidemics, war and migrations that affect public health throughout human history. Accordingly, while examining the effects of wars and migrations on public health; In the occurrence of epidemics (pandemic), war and migration environments have been found to be a reservoir (host) on infectious diseases. In addition, infectious diseases that cause epidemic diseases; It has been revealed that the global activities of judicial crime organizations, especially in the COVID19 process, have had a great impact on the areas where contaminated water is used, such as international trade, air and sea transportation, uncontrolled life, migration camps, and insufficient equipment. In addition to the fact that outbreaks greatly affect societies and human history, artificial effects such as wars and migrations become faster and easier to spread to the global area. If we look at the history in a general summary to show an example to this situation; Malaria of the crusaders, malaria and oriental boils of anzac soldiers, typhoid and dysentery of Napoleonic armies, America's cholera, plague and AIDS, Ottoman plague and tuberculosis, Polio and leprosy of the Middle East, Asia's flower and syphilis, China and Africa 's struggle with all infectious diseases other than leprosy and flowers caused these societies to become a breaking point in their history. The Coronavirus epidemic that started in 2019, which still continues today, is seen as an example of these breaking points in history; Unlike the epidemics mentioned above, it has been witnessed that it affects almost all continents. As a result; It has been concluded that wars and migrations that occurred throughout the history have been a major factor in the increase of infectious diseases and their transition to epidemic dimension.
\end{abstract}

\footnotetext{
* Doktora Öğrencisi, Uluslararası Süleyman Üniversitesi, İktisat Fakültesi, Uluslararası İşletme Doktorası Doktora Özel Öğrencisi, Hacettepe Üniversitesi Sağlık Bilimleri Fakültesi, Halk Sağlığı ABD

PhD Student, International Suleiman University, International Management PhD

PhD Special Student, Hacettepe University, Public Health PhD

ORCID 0000-0002-4007-1335

damlataskin.ufuk@gmail.com

*** Dr. Öğr. Üyesi, Hitit Üniversitesi, Antropoloji Bölümü, Fiziki Antropoloji ABD

Asst. Prof., Hitit University, Department of Anthropology, Physical Anthropology

ORCID 0000-0002-4603-2548

vahdetozkocak@gmail.com

Cite as/ Atıf: Taşkın, D., Özkoçak, V. (2020). kitlesel göçler ve enfeksiyon hastalıkları arasındaki ilişkiler kapsamında antropolojik değerlendirmeler: Koronavirüs (Covid-19). Turkish Studies, 15(4), 1105-1127. https://dx.doi.org/10.7827/TurkishStudies.44278

Received/Geliş: 16 June/Haziran 2020

Accepted/Kabul: 10 August/Ağustos 2020

Copyright $(\mathrm{C}$ MDE, Turkey

Checked by plagiarism software

Published/Yayın: 30 August/Ağustos 2020

CC BY-NC 4.0
} 
Structured Abstract: There are also many secondary causes that affect the cause and effect of wars, economic developments, social life and population movements. The wars that continued in the history process created serious events on both socio-cultural life and public health. These events are; it has created another chain of chain reactions that affect public health. This study aimed to examine the major events affecting public health in general terms. Diseases that are endemic in a certain region have been moved to other countries in various ways, allowing them to become pandemic and cause major deaths. The various ways that cause pandemic are more diversified with the development of technology today; commercial products, air and sea use, illegal activities of criminal criminal organizations, biological warfare, anti-vaccination actions, mass migrations, and health systems and inadequacies caught unprepared for an epidemic event. Solution suggestions will be presented by interpreting the research findings on the policies, precaution and prevention studies, treatment methods and international relations studies of the society on epidemic diseases by using qualitative and quantitative data.

The phenomenon of international migration is involved in civilizations, empires, management systems, social order, wars and diseases throughout history. As a structure, it has remained serious until today. The phenomenon of immigration, which had a great impact even in the skipping call on the world, changed its shell due to the changing life control of the 21st century; caused new immigration models and immigration classes. Although the causes and consequences of migrations are examined separately according to societies and even global area as different disciplines; It is determined that epidemic diseases, one of the results of the wars caused by these displacements, caused more deaths than the number of soldiers and even civilians who died on the front. Major diseases of these diseases are for; Influenza, Spanish flu and avian influenza outbreaks, scorpion cases and polio (polio) outbreaks, plague, tuberculosis, measles, flowers, syphilis, HIV (+) / AIDS, malaria, typhus, leprosy, cholera and typhoid, It is because there is a population increase or crowded life that will jointly emerge in dirty and unhygienic living environments to determine whether songs are counted as boils. it seems to be associated with diseases.

Syria makes Iraq and making immunization studies in the alarm dimension of the migration group from Iran geopolitical boundaries should be seen still in these risky countries are moving toward Turkey polio virus the place of arrival, both on the migration routes of both irregular migrants needed. Evidence of this situation can be given in the Polio epidemic that broke out in Syria in 2012 and in Iraq in 2013. It is seen that health problems in regions such as the Middle East and Africa continent and insufficient studies due to different reasons, war environments, famine outbreaks arising from situations such as famine, preventive and spreading activities can be prevented by providing adequate vaccination without sacrificing by surveillance systems of countries. Considering the living conditions in migration camps and migration routes, it turns out that these areas are the priority areas of these studies. Because, in the process of the epidemic, the whole world, including our country, shows that the country has to carry out vaccination and capacity building activities against polio importation in all provinces starting from the borders. Turkey can become although national immunization days and both polio as a result of the activities of other vaccination campaigns approved as a country where there are both cases of measles though this is that neighboring countries with viruses both diseases and open to migration to because of the virus. Especially that children in Syrian or other national immigration masses who fled the war environment posed an infection risk both among themselves and among the local people of the target region; it is thought that this risk should be studied with the attention that it may refine national health security.

National health security of the West in order to avoid a possible polio outbreak occurred could jeopardize Bank, Gaza Strip, Iraq, Lebanon, Egypt, Syria, Turkey and Jordan taking place within the scope of the emergency response are expressed in seven countries in seven regions. The reason for this has been the prediction that the spread of the virus will increase in the context of geopolitical locations and domestic health deficiencies. He stated that in the report of the World Health Organization (2018) of the polio virus that found a way of transmission by migration, there were no cases of polio from Syria in 2018. In addition, increased prevention of measles outbreaks in camps in war zones and in order to WHO and Turkey, which will be held simultaneously with cooperation between institutions in healthcare as polio and measles vaccination campaign has been launched. For coronavirus pandemics, which are effective all over the world today, it will be very useful in this respect that all countries act together and the treatment programs are common. 
It is not the society in which infectious diseases that occur in various ways and for different reasons appear at the beginning; it seems that it now affects the whole world and causes great destruction. The effects of these effects are only for public health, and the governance shape of the states and their religious forms have deeply understood the reality with their known pandemics and Coronavirus pandemic, the last pandemic throughout history.

Keywords: Healthcare Management, Business, Migration, Infectious Diseases, War, international relations, Anthropology

Öz: İnsanlık tarihinin şekillenmesinde devletlerin siyasi, sosyal, sağlık, ekonomik, idari ve askeri yönetim kararları etkili olmuştur. Bunlara ek olarak doğal afetler, coğrafik koşullar, modern teknoloji gibi tali nedenler de insanlığı etkileyerek bir dizi zincirleme olaya sebebiyet vermiştir. Çalışmamızın amacı olan savaş ve kitlesel göçler ise; insanlık tarihini ve toplumları bir dizi zincirleme olaylarla; sosyo-kültürel, ekonomik, hukuki, devletlerin yönetim biçimleri ve toplum(halk) sağlığı gibi alanları derinden etkilemiş ve değiştirmiştir. Bu çalışmada, insanlık tarihi boyunca toplum sağlığını etkileyen salgın hastalıkları, savaş ve göçler bağlamında neden-sonuç ilişkisi incelenecektir. Bu doğrultuda savaş ve göçlerin toplum sağlığına etkileri incelenirken; salgın hastalıkların (pandemi) meydana gelmesinde, savaş ve göç ortamlarının bulaşıcı hastalıklar üzerinde bir rezervuar(konak) olduğu görülmüştür. Buna ilaveten salgın hastalıklara neden olan enfeksiyon hastalıklarının; uluslararası ticaret, hava ve deniz yolu ulaşımı, kontrolsüz yaşam, göç kampları gibi kontamine su kullanımı yapılan yerler, yetersiz ekipmanlarla yapılan tarım ve hayvancılık çalışmaları, adli suç örgütlerinin küresel çaplı faaliyetlerinin büyük etkisi olduğu -özellikle COVID19 süreci boyunca- ortaya çıkmıştır. Salgınların, toplumları ve insanlık tarihini büyük ölçüde etkilemesine ilaveten savaş ve göçler gibi yapay etkiler ile de küresel alana yayılmaları daha hızlı ve kolay bir hale gelmektedir. Bu duruma örnek gösterebilmek amacıyla tarihe genel bir özetle bakılırsa; haçlı ordularının sıtma, anzak askerlerinin sıtma ve şark çıbanı, Napolyon ordularının tifo ve dizanteri, Amerikalıların kolera, veba ve AIDS, Osmanlı'nın veba ve verem, Orta doğu'nun çocuk felci ve cüzzam, Asya'nın çiçek ve frengi, Çin ve Afrika'nın cüzzam ve çiçek harici tüm enfeksiyon hastalıkları ile mücadelesi, bu toplumların tarihlerinde bir kırılma noktası haline gelmesine sebebiyet vermiştir. Günümüzde de halen devam eden 2019 yılı başlangıçlı Coronavirüs salgını, tarihteki bu kırılma noktalarına örnek olarak görülmekte; yukarıda belirtilen salgınlardan farklı olarak hemen hemen tüm kıtaları etkilediğine tanık olunmuştur. Sonuç olarak; tarih boyunca meydana gelen savaş ve göçlerin, bulaşıcı hastalıkların artmasında ve salgın boyutuna geçmesinde büyük bir etken olduğu sonucuna varılmıştır.

Anahtar Kelimeler: Sağlık Yönetimi, İşletme, Göç, Bulaşıcı Hastalıklar, Savaş, Uluslararası İlişkiler, Antropoloji

\section{Giriş}

İnsanlık tarihi boyunca toplum sağlığının korunmasına yönelik en fazla katkıda bulunan kişinin, mikroorganizmalar buluşu ile Louis Pasteur olduğu bilinmektedir. Pasteur, mikroorganizmaların genellikle organik ortamlarda ve kendiliğinden ortaya çıktığı hipotezini çürüten germ (hücre) kuramını öne sürerek "bakteriyolojinin altın çağı" nı başlatmıştır. Germ kuramı ise, günümüzde antibiyotiklerin yapımında kullanılan klinik mikrobiyoloji ve modern tıbbın kilometre taş1 olarak sayılmaktadır (Tözün \& Sözmen, 2014:60). Bakteriyolojinin altın çağı öncesinde yaşayan hekimler; cüzzam, verem, veba gibi bulaşıcı hastalıklar konusunda çok az gelişme kaydetmiş; hatta ilkçağ tıbbı bilgilerine çok az bilgi ilave ettikleri tespit edilmiştir. Buna karşın Pasteur, dönemin gerek tıbbi ve çevresel faktörlerine; gerek siyasi otorite, yönetim şekli, din kuralları gibi zorlayıcı şartlara rağmen bakteriyolojinin altın çağına öncülük etmiştir. Bunun için mikroskopunun yardımı ile mayalanmanın mikroorganizmalar tarafindan meydana gelen bir parçalanma olayı olduğunu ortaya çıkarmıştır. Tıp tarihindeki bu buluş, ilerleyen dönemlerde mikroorganizmalar ile bulaşıcı hastalıklar ilişkisine dair yapılan çalışmaların temel dayanağı olmuştur. Ayrıca 1879 yılında Avrupa'da başlayan tavuk kolerası salgınının çözümünde bu keşfi kullanmış; yeni ve hastalık yapıcı gücü fazla (virulan) kolera vibrionu elde edebilmeyi amaçlamıştır. Bunun için ise; eskimiş kültürleri ve başka bir yerden aldığg virüsleri tavuklara enjekte ederek, bu 
virüslerin tavuklar üzerinde kolera yapmadığı hipotezini ortaya atmıştır. Bu deney çalışması ile bulaşıcı hastalıkların, toplum üzerindeki etkisini azaltmak için bir çeşit bağışıklık sağlayıcı tedavi olduğu fikrini ortaya çıkarmıştır. Bağışıklama tedavisi için sağlam insanlar üzerinde virulansı azaltılmış mikroorganizma verilmesi sayesinde kuduz aşısının geliştirilmesini sağlamıştır. Bilinen tarihte ilk kez -7 Temmuz 1885- tarihinde sağlıklı ve gönüllü bir çocuk üzerinde kuduz aşılaması yapılmış ve sonrasında $13 \mathrm{kez}$ enjeksiyon uygulaması ile - önceleri serum ile- hastanın tedavi edildiği gözlenmiştir. Bu sonuç doğrultusunda kuduz aşısı tedavisi geliştirilerek; salgın hastalıkların tedavisine yönelik tarihteki ilk büyük adım atılmıştır (Eren, 1989:1).

Salgın hastalıklar, tarihin en eski dönemlerinden beri tüm toplumları doğrudan veya dolaylı bir şekilde etkilemiştir. Bu durumun başlıca nedenleri ise; elverişsiz yaşam koşulları ile sağlıksız ortamlar, ekolojik dengenin bozulması, kıtlıklar, savaşlar, doğal afetler, göçler, sağlık politikaları ve hukukun esnetilmesi gösterilmektedir. (Kılıç,2004:11). Özellikle insan ve çevre arasındaki sürekli ilişki, enfeksiyon hastalıklarının oluşmasına olanak vermiş; başta tarım ve hayvancılık faaliyetleri ile birlikte virus, mantar ve bakterilerin (mikroorganizmalar) bahçeler, köyler veya araziler üzerinde insana geçebilmesine neden olmuştur. Dolayısıyla tarım ve hayvancılıkla uğraşan çiftçi ve diğer toprakla ilgilenen meslek gruplarının, bu mikroorganizmaların neden olduğu enfeksiyon hastalıklarına yakalanma olasılı̆̆ını arttırmıştır. Bunun nedeni ise; tarımda çalışanların hayvanlar ve bitkiler ile doğrudan temas etmesi sonucunda 1sırık, zehirlenme, paraziter hastalıklar, çeşitli alerjik reaksiyonlara maruz kalması gösterilebilir. Ayrıca kentlere yakın bulunan tarım ve hayvancılık yerleşimlerinde kullanılan kimyasal ve biyolojik malzemelerin halk sağlığını tehdit edici etkileri, kentsel alanlarda enfeksiyon hastalıklarının ortaya çıkmasında da etkili olmaktadır (Yavuz, 2013:4).

Enfeksiyon hastalıkları yalnızca yerleşik yaşamlar üzerinde değil; aynı zamanda göçebe toplulukların üzerinde de büyük etki yaratmaktadır. Tarih boyunca toplumlar, göçebe toplulukların, göç yolları boyunca farklı bölgelerden ve farklı iklimlerden geçmelerine ek olarak sağlıksız beslenme, hijyen eksikliği koşullarının bu toplumlarda bulaşıcı hastalıkların görülmesini kolaylaştırdığını tecrübe etmiştir. Bu bağlamda insanlık tarihinin tecrübe ettiği diğer bir konu ise; insanlığın göçebe yaşamdan yerleşik yaşama geçmeleri ile birlikte hayvanların da evcilleştirilmesi sağlanmış; bunun sonucunda insanlığın etoburlaşması (hayvansal et tüketimi) ile protein tüketiminin artmasına neden olduklarının görülmesidir. Dolayısıyla ortak yaşam alanları, hayvanlarda bulunan patojenlerin hızla çoğalmasına ve akabinde bazı hayvan hastalıklarının insanlara geçmesine zemin hazırlamıştır. İnsan toplulukları ile hayvanlar arasındaki yerleşik yaşam ilişkisi, hayvanları evcilleştirmenin neden olduğu enfeksiyon hastalıkları ile değişim geçirmiştir. Bunun doğal sonucu olarak bu hastalıkların artık insanlara özgü hastalıklar haline dönüşmesine neden olmuş; böylece insanlar üzerindeki enfeksiyon hastalıklarının, hayvansal hastalıklarının yakın akrabası olduğu hipotezini kurmuştur. Yerleşik yaşama geçilmesinden günümüze kadar geçen süre boyunca -tahmini on bin yıl- köpeklerle altmış beş, sığırlarla elli, koyun ve keçilerle kırk altı ve domuzlarla kırk iki tür enfeksiyon hastalığının paylaşıldığı belirlenmiştir. Bu tespit göç ve iskân konusunun halk sağlığı üzerindeki olumsuz etkilerinin önemini göstermekte; göç grupları içinde yer alan bir enfeksiyon hastalığının, göç edilen bölgeye taşınmasına ve yayılmasına da etkisi olduğu sonucunu doğurmaktadır (Ponting, 2000: 197).

İnsan üzerindeki hastalıkların veya rahatsızlıkların nasıl ve ne şekilde ortaya çıktığını anlayabilmek için "Biyopsikososyal model" hazırlanmıştır. Bu model ile gerek göçmenler üzerinde; gerekse yerleşik toplumlar içinde ortaya çıkan hastalıkların doğru ve etkili tedavisinin yapılması amaçlanmıştır. Biyopsikososyal modele göre; "hem sağllk hali hem de hastalık hali; sadece hücrelerdeki bir bozukluktan dolayı değil (biyolojik sebeplerden dolayı değil), hem biyolojik, hem psikolojik ve hem de sosyal değişkenlerin karmaşık etkileşimleri ile şekillenmekte ve hiçbiri diğerinden ayrılarak kategorize edilememektedir". Bu tanım, hasta olma halinin yalnızca tıbbi nedenlerle değil; aynı zamanda psikolojik ve sosyal nedenlerle de oluşabileceğini belirtmektedir. Tibbi unsurlardan olan biyolojik unsurlara örnek olarak; immün sistem veya bağışıklık sistemi, 
dokuları ve organ sistemleri gösterilebilir. İlaveten psikolojik unsurlara örnek olarak ise; kişinin stres ve kaygı düzeyi, travma ve şiddet durumları, baskı, işkence, savaş ve göç sürecinin yarattığı diğer psikolojik problemler sayılabilir. Son olarak hem tıbbi unsurlara hemde psikolojik unsurlara eklenebilen sosyal unsurlara örnek olarak ise; kişi veya toplumların gelir düzeyi, yaşam koşulları, kültürel ve dini etkiler, göç ve iskân koşulları gösterilebilmektedir (Yanık, 2018: parag.4-5).

Taşkın (2018: 36)'e göre; göç ve iskân olgusu biyo-psikososyal model ile ele alındığında; göçlerin yoğunlaşmasıyla birlikte halk sağlığı üzerinde de ani ve hızlı bir çevre değişiminin meydana geldiğini; bu durumun toplumlar üzerinde olumsuz sonuçları olduğunu belirtmiştir. Ayrıca göçlerin hem sağlık hem sosyo-kültürel anlamda en çok olumsuz etkilediği kitlenin engelli bireyler olduğunu dile getirmiştir. Bunun nedeni olarak ise, engelli bireylerin mevcut hastalıklarının yanı sıra göç olgusuna maruz kalmaları ve zaten zayıf bağışıklık sistemleri yüzünden enfeksiyon hastalıklarına açık olmaları gösterilmiştir. Diğer bir neden olarak ise sosyal unsurları göstererek; engelli bireyin gelir durumu, sağlık hizmetlerine erişimdeki güçlükleri ve göç etme zorluklarının etkili olduğu belirtilmiştir. Bu bağlamda; göç ve enfeksiyon hastalıkları ilişkisi, göç kabul eden ülkeleri hem kendi vatandaşları açısından hem kabul ettiği göçmenler ve engelliler açısından tedirgin eden bir halk sağlığı sorunu olmaktadır. Çünkü göç olgusu ve göç kampları kızamık, kolera, sıtma, tüberküloz, veba, influenza ve akut solunum yolu enfeksiyonları, hepatitler, HIV/AIDS ve ishalli enfeksiyon gibi bulaşıcı hastalıklarının meydana gelmesi ve yayılması için büyük bir risk alanı oluşturmaktadır. Bu nedenle devletler, göçmenler için önleyici-koruyucu sağlık hizmetlerinin temin edilmesini bir halk sağlı̆̆ tehdidi olarak görmeye başlamış; hukuk kuralları ve sağlık politikaları ile göç mevzuatını geliştirmeye başlamıştır.

İnsanlık tarihi ve halk sağlı̆̆ını ilgilendiren konular her geçen gün değişim ve gelişim göstermektedir. Bu değişim ve gelişimler üzerinde ciddi bir etkisi olan salgın hastalıklar, kitlesel göç olguları ve birbirleriyle olan etkileşimleri insanlık tarihine de yön vermeye halen devam etmektedir. Günümüz teknolojisi, tıbbı ve sağlık politikaları bu etkileşimin kontrolünün sağlanması ve yasal normlarla geliştirilmesi için ulusal ve uluslararsı çalışmalarına ağırlık vermiştir. Böylece modern toplumlar insan ve bulaşıcı hastalık ilişkisi konusunda araştırma alanları genişletilmiş; yeni tekniklerden faydalanılmaya başlamıştır. Bu yeni tekniklerden biri ise Antropoloji bilimi içine giren "Antropometri" disiplini olup; kişiler veya gruplar arasındaki anatomi, coğrafya, meslek grupları, engellilik, cinsiyet, uyruk veya hüviyet gibi çeşitli farklılıkları veya benzerlikleri tespit ederek

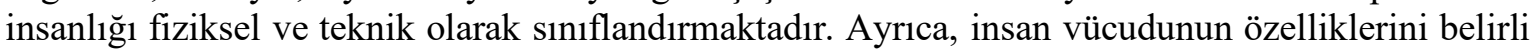
ölçüm yöntem ve prensiplerine göre ayırarak -büyüklügü̈ ve yapı özellikleri dahil- uzunluk, genişlik, çevre, yükseklik, kalınlık, açı, ağırlık ve cilt katlama kalınlığı gibi incelemeler ile sınıflandırılmasını yapmaktadır. Bu sınıflandırma ile dünya üzerindeki her insan için- göçmenler dahil- belirleyici bir kimliklendirme yöntemi oluşturulmakta; ayrıca birçok hastalığı tespit edici bilimsel bir yöntem olarak salgın ve göç ilişkisinde önemli rol oynadığı görülmektedir (Özkoçak, 2018:30).

Aydoğan \& Metintaş (2017:38-41)'e göre devletler, göçmenlere ait nüfus kayıtlarını düzenli ve istisnasız olarak kayıt altına alınmasını sağlayarak, halk sağlığını ve ulusal güvenliğini önleyici bir tedbir sağlanacağını dile getirmiş̧ir. Bu tedbir ile kamu düzeni üzerinde risk oluşturan veya oluşturması muhtemel göç nüfusunun problemlerini tespit edebilebileceği belirtilmiştir. Böylece göç grupları ile enfeksiyon hastalığına ilişkin bağışıklama ve tedavi sürecinin başlanmasıyla; olası bir enfeksiyon hastalığının engellenmesi amacıyla acil eylem planlarının uygulamaya geçileceğini dile getirmiştir. Acil eylem planları içerisinde; göç kampları ve çevre sağlı̆̆ iyileştirilmesi, gıda ve su temizliği sağlanması ve bu odak grubun toplum sağlığı açısından kontrol altına alınması gerektiği de eklenmiş̧ir. Bunun nedeni olarak; kişi veya grupların yetersiz ekonomik koşulları, beslenme problemleri, kötü hijyen durumları, kalabalık yaşam, alt yapı yetersizliği ve sağlık kuruluşuna ulaşmadaki güçlükler gösterilmiştir. Ayrıca göç kampları ve göç yolları üzerindeki hasta kişilerin, ilaç tedariği hususunda sorun yaşadığını ve kesin tedavi sağlanamadığı gerekçesiyle hastalığı "taşıyıcı" olarak yaşadıklarını; bu durumun da salgın riskinin artmasına neden olduğunu belirtmiştir. 


\section{Savaş ve Salgın Durumları Arasındaki İlişkiler}

Dünya'nın bilinen en eski uygarlığı olan Sümer uygarlı̆̆ı, yazı ve astronomi de olduğu gibi; savaş kavramını da literatüre kazandırmıştır. Sümer uygarlığının Mezopotamya bölgesinde yaptığ sürekli savaşlar sonucu, tarihte ilk yazılı kurallarının oluşmasına katkı sağlanmıştır. Ancak Mezopotamya'da ortaya çıkan ve tarihte bilinen en eski - korunmuş- yazılı kanunların MÖ 1760 yıllarında yazılan Hammurabi Kanunları olduğu belirtilmiştir (Işık, 2018:63) Hammurabi Kanunları içerisinde hukuk ve sağlık ilişkisinin incelendiği şu ifadelerle gösterilmektedir:

"Eğer bir adam bir işçi (köle) kiralarsa, (o) ölür (veya) kaybolur (veya) kaçarsa, işi terkederse veya hastalanırsa, bir günlük emeği karşıllğında bir BAN arpa sayacaktır (...) Eğer bir hekim, bir adamın kırık kemiğini iyileştirir ve hasta bir insanı iyileştirirse hekime 5 şekel gümüş ödenektir...” (Tosun ve Yalvaç, 1989: 211).

Yukarıda belirtilen ifadeyle Hammurabi Kanunları, sağlı̆̆ın ve hastalıkların önemini yazılı hukuk ilkeleri ile açıkça belirttiği görülmektedir. Ayrıca bu ifade, eski çağlarda halk sağlığına dair yapılan çalışmaların ve kuralların anlaşılmasına yönelik günümüze 1şık tutan bir metin olmasını sağlamıştır. Tarihte ilk belgelendirilen salgının (pandeminin) ise 426-329 yılları arasında Atina'da aşırı artan nüfus ile savaşların neden olduğu göçlerin başlamasıyla gerçekleştiği bildirilmiştir. Aynı dönem Atina ile ticaret yapan Mısır ve Etiyopya gibi ülkelerde de bu hastalığın görülmeye başlaması; ticaret ve göçlerin salgınlar üzerindeki hızlı etkisini de göstermiştir. Ayrıca bu salgın; sadece Atina'da nüfusun \%30'unun hayatını kaybetmesine yol açmış; hastalığın M.Ö. 430-428 ve 427-426 yılları arasında iki kez daha tekrarlanmasına ve farklı toplumları etkilemesine neden olmuştur (Sirman, $2020: 42$ ).

Tarih boyunca tekrarlanan salgın hastalıklar, toplumların can güvenliklerini sağlamak için yaşadıkları yeri terketmelerine ve başka bir ülkeye göç etmelerine neden olmuştur. Bu duruma örnek olarak; Türklerin anayurdu olarak kabul edilen Orta Asya'dan; diğer tüm kıtalara yaptıkları kitlesel göç hareketleri gösterilebilir. Tarihte bu göç hareketine "Kavimler Göçü" adı verilmiş; göçün sebepleri olarak ise; Çin ve Moğol baskıları, artan nüfus ve yetersiz yaşam alanları, iklim koşullarının kuraklık ve şiddetli kış dönemlerinin getirdiği yetersizlikler, kavimler arası çatışmalar ve hayvancılıktan doğan salgın hastalıklar olarak gösterilmiștir. Kavimler göçünün başladığı topraklarda görülen bu salgın hastalıkların göç yolları boyunca taşınması, göç edenlerin gittikleri bölgelere de bu hastalıkları götürmesi olası bir salgın (pandemi) oluşumuna zemin hazırlamıştır (Kılıç, 2004:106).

K1lıç (2014:97)'e göre; orta ve yeniçağ dönemlerinde meydana gelen salgın hastalıkların, devletlerin siyasi ve askeri düzenleri üzerinde bazı olumsuz etkiler yarattığını dile getirmiştir. Bu etkilerden bazıları şu şekilde sıralanmıştır:

- Savaşların, bulaşıcı hastalıkların meydana gelmesinden dolayı kaybedilmesine,

- $\quad$ Ekonomik faaliyetlerin durma noktasina gelmesine,

- Devlet yönetimlerinin ve sağlik politikalarının değiştirilmesine,

- $\quad$ Ulusal güvenlik açığının oluşmasına ortam yaratması olarak gösterilmiştir.

Ayrıca yakınçağdan bugüne kadar devletlerin, toprak veya ekonomik kazanç sağlaması amacıyla bulaşıcı hastalıkları silah haline getirip biyolojik savaş unsurları olarak kullanması ile birlikte salgın hastalıkların savaş silahı olarak görülmesine yol açmıştır. Buna örnek olarak; insanlık tarihinin en büyük nükleer kullanımın deneyimleri olan 1945 yılı Hiroşima ve Nagazaki bombalamaları verilebilir. Bu olay ile bölgedeki tüm yaşam formları ölümle yüzleşmiş ve yok olma tehlikesiyle karşı karşıya gelmiş olup; nesiller boyu aktarılan genetik bozukluklar ve kanserler gibi hastalıklara da neden olmuştur. Bu durum nükleer savaşın aynı zamanda biyolojik savaşta olduğunu göstermiştir. Ayrıca radyasyonun yol açtı̆̆ zararlar, birkaç nesil sonrasına da aktarılarak günümüze kadar etkilerini taşımıştır (Gölçek, 2019:289). 
Kırık \& Özkoçak (2020: 138)'ün Covid-19 pandemisi konulu çalışmasında; günümüzde olası bir biyolojik savaşta kullanılması için çeşitli yollarla -göçler de dahil- ülkelere enfeksiyon hastalıklarının tehdit unsuru olarak kullanılabileceği öngörülmüştür. Ayrıca ülke dışında yapılan bir savaş sonrasında ülkelerine geri dönen askerlerin ve işçilerin ülkeden-ülkeye hastalık taşıyabileceği ihtimali de düşünülmektedir. Bu durumun gerçekleşmesi halinde ülke siyaseti ve dış politikası da olumsuz etkilenebilecek ve büyük yıkımlara neden olabilecek salgın boyutuna geçebilecektir. Salgınlar, toplumları kitlesel göçlere ve toplu can kaybı vakaları seviyesine kadar getirebilecektir. Salgın hastalıkların tarih boyunca askeri orduları ve toplumu yapay felaket düzeni ile kitlesel ölümlere götürdügü bilinmektedir. Buna ek olarak seyahat halinde olan veya yerleşik olmayan toplulukların; özellikle askeri orduların veya göçebe grupların kullandıkları kontamine su ve rezervuarlarının insan sağlığına risk oluşturması sonucu salgın hastalıklar doğurabileceği de tespit edilmiştir. Ayrıca bu konunun daha detaylı analizi çalışmamızın savaş ve salgın hastalıklar başlığı altında incelenecektir.

Göç ve iltica olgusu, yalnızca coğrafi olarak yer değiştirme olayı olmayıp; toplumların birbirleri ile etkileşimi sonucu beraberinde birçok yönden yapısal değişikliği de sağlayabilecek güçte bir olgu olmaktadır. Değişime söz konusu alanlar, sadece sosyal yaşamı etkilememekte; aynı zamanda toplum sağlığını da ciddi şekilde etkilemektedir. Bu doğrultuda göç ve iltica olgusuna neden olan durumlar iki başlığa ayrılmaktadır. Bunlardan ilki çekici nedenler olmak üzere; iş bulma ihtiyac1, mevcut yaşamdan daha iyi yaşam arzusu, politik ve dini seçimler, eğitim ve sağlık hizmetleri ile güvenlik ihtiyacı olmaktadır. İkincisi ise itici nedenler olup; savaş, çatışma ve iç karışıklıklar, istikrarsız yönetim şekilleri, zorlu yaşam koşulları, yetersiz sağlık hizmetleri, olağanüstü haller, sosyal eşitsizlik, baskı rejimi ve salgın hastalıklar olarak sayılmaktadır (Doğruyol, 2007:12-18). Bu duruma örnek olarak, başta Orta Asya olmak üzere farklı bölgelerden Anadolu coğrafyasına yapılan kitlesel göçler ve büyük savaşlar verilebilir. 1914-1918 yılları arası Birinci Dünya Savaşı esnasında Osmanlı Devleti'nde dolayısıyla Anadolu coğrafyasında kolera, tifüs, veba, frengi gibi salgın hastalıklar cephedeki askerleri ve sivil halkı büyük oranda etkilemiştir. Sivil halk arasında salgın hastalıklardan dolayı gerçekleşen ölümler ise; cephede hayatını kaybeden askerlerin sayısından fazla olduğu tespit edilmiştir. (Çalık \& Tepekaya, 2006:210).

Tablo 1: 1914 Öncesi Bazı Savaşlarda Kayıplar (Özdemir, 2005: 8).

\begin{tabular}{|c|c|c|c|c|}
\hline $\begin{array}{c}\text { Ordu } \\
\text { Adı }\end{array}$ & Yı1 & Asker & Çatışmada ölümler & $\begin{array}{c}\text { Hastalıklardan } \\
\text { ölümler }\end{array}$ \\
\hline $\begin{array}{c}\text { Kırım } \\
\text { savaş1 } \\
\text { (Fransiz) }\end{array}$ & $1854-1856$ & 301.000 & 20.000 & 75.000 \\
\hline $\begin{array}{c}\text { Fransa- } \\
\text { Prusya } \\
\text { savaş1 } \\
\text { (Prusya) }\end{array}$ & $1870-1871$ & 800.000 & 28.300 & 14.904 \\
\hline $\begin{array}{c}\text { Rus- } \\
\text { Japon } \\
\text { savaş1 } \\
\text { (Japon) }\end{array}$ & $1904-1905$ & 420.000 & 58.887 & 27.158 \\
\hline $\begin{array}{c}\text { Rus- } \\
\text { Japon } \\
\text { savaş1 } \\
\text { (Rus) }\end{array}$ & $1904-1905$ & 490.000 & 47.608 & 27.830 \\
\hline
\end{tabular}

Tablodan görüldüğü üzere; tarihin bazı dönemlerinde meydana gelen savaşlar ve bu savaşlar sırasında meydana gelen bulaşıcı hastalıkların oranları verilmiştir. Anlaşılacağ 1 üzere savaşlarda ortaya çıkan bulaşıcı hastalıklardan ölen askerlerin sayısı; savaş ve çatışmaların neden olduğu ölüm oranlarına çok yakın veya daha fazla olduğu görülmüştür. Bu durum, savaş ortamının bulaşıcı 
hastalıklar için verimli bir konak olduğunu; bu konak üzerinde yaşayan veya buradan geçiş yapan insanlar üzerinde ölümcül etki yapabildiğini hatta savaşların seyrini değiştirebildiği sonucunu vermektedir.

Tablo 2: Türkiye'de Son Dönemde Yaşanan Salgınlar (Ergönül, 2016:7).

\begin{tabular}{|c|c|c|}
\hline $\begin{array}{c}\text { İnfeksiyon } \\
\text { hastalığı }\end{array}$ & Görülen yıllar & Etkilenen insan sayıs1 \\
\hline $\begin{array}{c}\text { Kırım-Kongo } \\
\text { Kanamalı Ateşi }\end{array}$ & 2002 & $>10000$ \\
\hline Kuş gribi & 2005 & $>100$ \\
\hline $\begin{array}{c}\text { Hanta virüs } \\
\text { infeksiyonu }\end{array}$ & 2008 & $>100$ \\
\hline Tatarcık Ateşi & 2008 & $>10000$ \\
\hline Domuz Gribi & 2009 & $>200000$ \\
\hline Batı Nil Ateşi & 2010 & $>100$ \\
\hline Mers-CoV & 2013 & $>75000$ \\
\hline Norovirus & 2016 & $>200000$ \\
\hline $\begin{array}{c}\text { Coronavirus- } \\
\text { COViD-19 }\end{array}$ & 2020 & \\
\hline
\end{tabular}

Verilen tabloda; infeksiyon hastalıkları türleri ile hastalıkların görüldüğü yıllarda etkilenen insan sayısına dair sayısal veriler gösterilmiştir. Bu veriler 1şığında 2002-2020 yılları arasındaki en yüksek vaka sayısının 2009 Domuz Gribi dönemiyle 2020 Coronavirus dönemi olduğu görülmüştür. Buna ek olarak, Ergönül (2006:7)'a göre, Türkiye'de henüz saptanmayan fakat; her an nüksedebilecek Zika virüs ve Chikungunya virüs infeksiyonları salgın potansiyeli olduğunu ve önemli bir tehdit oluşturduğunu belirtmiştir. Bu akademik öngörünün 2020 yılında tüm dünyay1 etkisi altına alan Coronavirus pandemisi ile kısmen gerçekleştiği sonucuna varılabilir.

\section{Salgın Hastalıklar Tipolojisi}

\subsection{Atina Salgın}

Tarihte bilinen ilk salgın olmamakla birlikte; günümüze kadar ulaşan ilk pandemi bilgisinin, milattan önce 426-429 yılları arasında gerçekleşen Peloponez savaşı ile Yunanistan'ın Atina şehrinde tanımlayan bir salgın hastalığın olduğu belirtilmiştir. Bu hastalık, dönemin koşulları ve kullanılan dilin anlaşılmasındaki güçlükler nedeniyle, daha sonraki dönemde yaşayan tıp bilgini Hipokrat ile tarihçi Thucydides tarafindan belgelenmesine neden olmuştur. Böylece tarihte ilk belgelendirilen salgının Atina Salgını olduğu ortaya çıkmıştır (Sirman, 2020:43).

Atina Salgınına veba hastalığının neden olduğu ve tahmini olarak 100.000 ölüm ile sonuçlandığı bildirilmiştir. Veba hastalığınnın salgın boyutuna geçmesine ise; Peloponez Savaşının kötü yaşam koşulları, temiz suya erişimdeki zorluklar ve sağlık hizmetlerinin yetersizliğinin yol açtığı belirtilmiştir. Böylece bu salgın yalnızca savaş taraflarını değil; aynı zamanda bütün Yunanistan tarihini ve dünya tarihini değiştiren bir felaket olarak tarihe geçmiştir (Arkeofili, 2020).

\subsection{Grip Salgınları ve Pandemileri}

Akın (2020)'e göre; influenza, üst solunum yolu, burun, boğaz ve bazen akciğerleri tutan bir infeksiyon olmaktadır. Semptomları yüksek ateş, başağrısı ve öksürük ile seyretmekte; yaklaşık 1 hafta sürebilmektedir. Her sene nüfusun \%5-15'ini infekte ederek; tüm dünyada her sene tahmini 35 milyon kişinin infekte olduğu belirtilmiştir. Ayrıca tüm dünya'da her sene yaklaşık olarak 250-500 bin kişinin (çoğu yaşlılar) influenzadan dolayı öldüğü bildirilmiş̧tir. Orthomyxoviridae ailesinden olan influenza'nın A, B ve C olmak üzere 3 türü bulunmaktadır. Bunlar sırasıyla şu şekildedir: 
(a) A ve B yıllık epidemilere neden olmaktadır,

(i) Ilıman bölgelerde mevsimsel olarak,

(ii) Tropikal bölgelerde yılboyu görülmektedir

(b) $\quad \mathrm{A}(\mathrm{H} 1 \mathrm{~N} 1)$ pandemilerden sorumlu olmaktadır,

(c) C hafif hastalık olarak influenza'nın A, B ve C türü gruplandırılmıştır. (L. Akın, görüşme, 10 Ocak 2020).

İnfluenza diğer adıyla üst solunum yolları enfeksiyonları (grip, nezle, gribal enfeksiyonlar, soğuk algınlığı vb.) A grubu içerisinde yer alan kuşlar, domuzlar, atlar, deniz memelileri ve insanları kapsamaktadır. Bu doğrultuda insanlar üzeride epidemik salgınlara A ve B türünün; pandemilerde ise $\mathrm{A}(\mathrm{H} 1 \mathrm{~N} 1)$ türünün sorumlu olduğunu tespit edilmiştir. Buna örnek olarak domuz gribi ve tavuk vebası salgınları gösterilebilir (Klimud, t.y.: 3-4). Çalışmamızda bu hastalıklar bir sonraki bölüm olan 2.4 Kuş Gribi başlığı altında incelenecektir.

Tarihte bilinen en eski influenza pandemisinin 1580 y1lına ait olmasına karşın; influenza virüsün ilk kez 1933 tarihinde Londra-National Institute for Medical Research kuruluşundan Willson Smith tarafından etkenleri izole edilmiştir. Bilinen en büyük pandeminin ise 1918-1919 yılları arasında "İspanyol Gribi” olarak adlandırılan salgın olduğunu ve tahmini 21 milyon kişinin ölümüne yol açtığı bilinmektedir. Bu salgın sonrasında yapılan çalışmalar sonucunda 1940 yılında ilk kez influenza aşısı geliştirilmiştir. Ayrıca 1960 yılında bu aşı için tedavi ve profilakside kullanılan amantadin geliştirilmiş olup; tedavi yöntemlerine artık salgının çıkış noktası ve etkenleri de dahil edilerek influenza adı verilmiştir. Bu hastalığın epidemilerinin Türkiye gibi 1lıman iklim kuşağında -kuzey yarım kürede sıklıkla Ekim-Nisan ayları arasında ortaya çıktığını; güney yarım kürede ise Mayıs-Eylül ayları arasında meydana geldiği ortaya çıkmıştır. Buna ilaveten tropikal bölgelerin iklim koşulları nedeniyle tüm yıl bu hastalığın görülebileceği dile getirilmiştir (Şanlı, 2020:8).

Anadolu Coğrafyası'nda M.Ö 412 yılında şimdiki adıyla Tekirdağ’a bağlı Marmaraereğlisi olan 'Perinthus' daha önce hiç görülmeyen bir bulaşıcı hastalık ile karşı karşıya gelmiştir. Bu hastalığa halk tarafindan "Perinthus Öksürüğü" adı konulmuş olup; günümüzde grip olarak tanımladığımız hastalığa işaret etmişlerdir. Perinthus adı verilen -günümüzde grip- hastalığının ortaya çıkma nedeni olarak kuşlarda -özellikle su çevresinde bulunan kuşlarda- bulunarak çeşitli yollarla domuzlara bu virüsün taşındığı ve insanlara geçtiği gösterilmiştir. Ancak zamanla meydana gelen mutasyonlar sonucu gribe neden olan virüsün hastalık yapıcı özelliği ve vektörleri artmış; bu yüzden epidemi salgınları haline gelmesine neden olduğu belirtilmektedir (Sirman, 2020: 45).

\section{3 İspanyol Gribi ile Funston Kampı}

Özdemir (2005:309)'a göre; 1917 y1lında askeri orduların eğitim gördüğü ABD’nin Funston askeri kampında, nedeni belirlenemeyen ve aniden ortaya çıkan bir tür grip salgını meydana gelmiştir. Bu grip salgınına "1918 İspanyol Gribi pandemisi" adı verilerek sadece bir seneden az bir süre içinde tahmini 40 ile 100 milyon arasında ölüme neden olduğu belirtilmiştir. Ayrıca bu grip salgınından ölenlerin sayısının; Birinci Dünya Savaşında ölenlerin sayısından çok daha fazlası olduğu belirlenmiştir. Bu durum dönemin sağlık kayıtları tarafından günümüze kadar ulaştırılmış; amerikalı asker ölümlerinin \%80'inin grip salgınından meydana geldiği ifade edilmiştir. İlaveten bazı Çinli kaynakların bu grip virüsünün, uzun zamandır Avrupa'daki göçmenler ve askeri birlikler içinde zaten bulunduğunu; fakat kimyasal silahlar ve diğer savaş koşullarının ordunun yaşam ortamını sınırlandırması ile yayılmasına hız kazandırdığı belirtilmiştir (Toraks, 2020).

Spinney (2017)'nin ispanyol gribi hakkında yaptığı çalışmaya göre; ispanyol gribi ABD nüfusunun binde beşinin -550 bin kişi-; Hindistan ise nüfusun yüzde 5,2'sini -17 milyon-kişinin öldüğü belirtilmiştir. Ayrıca İspanyol gribi'nin tüm zamanların en büyük salgınlarından biri olduğunu ve toplumun tüm kesimlerine ulaştı̆̆ını ifade etmiştir. Bu duruma örnek olarak ABD'nin 
New York eyaletinde yaşayan en fakir göçmenlerden İspanya kralı Franz Kafka'ya, Hindistan'da yaşayan ünlü düşünür Mahatma Gandhi ve ABD Başkanı Woodrow Wilson'a kadar tüm dünya'daki insanların üçte birini enfekte ettiğini göstermiştir.

\subsection{Kuş Gribi, Tavuk Vebası ile Domuz Gribi (H1N1)'nin Ortaya Çıkışı}

Avian influenza veya diğer adıyla kuş gribi hastalığı, influenza A türü virüslerinin neden olduğu bulaşıcı bir hayvan hastalığı olmaktadır. Kuş gribine neden olan virüs doğal olarak kuşlarda görülmekte olup; insanlara bulaşma özelliği taşımamaktadır. Ancak hayvan kümeslerinde meydana gelen bir salgın sırasında; hasta hayvanların dışkılarıyla çıkartılarıyla kirlenen yüzeyler, insanların da teması sonucu bu virüsün insana bulaşmasına olanak vermektedir. Böylece insana bulaşan kuş gribi vakalarının semptomları basit grip belirtilerine benzemekte; şiddetli solunum yolu hastalıkları görülmektedir. Kuş gribi vakalarının salgın boyutuna geçmemesi için hayvancılık faaliyetleri titizlikle yönetilmesi, kontamine suların kullanıldığı yerler- göç kampları dahil- kontrol edilmesi, şehir merkezlerinden uzak bölgelerde hayvancılık yapılması fayda sağlayacaktır (Acar \& Beşirbellioğlu, 2005:345).

Kuş gribi (H5N1) hastalığının 2003-2009 yılları arasında tüm dünyada yaklaşık 423 vakaya neden olduğu ve 423 vakanın 258'inin hayatını kaybettiği belirtilmiştir. Bu salgın Çin'in Hong Kong bölgesinde başlayarak ilerleyen zamanlarda Mısır, Vietnam, Endonezya, Kamboçya, Azerbaycan gibi farklı bölgelerden toplulukları etkilemiştir. Buna örnek olarak vaka sayıları şu şekilde belirtilmiştir:

Endonezya (141 olgu/115 ölüm),

Vietnam (111/56),

Misir (68/23),

Çin $(38 / 25)$,

Tayland (25/17),

Kamboçya (8/7),

Azerbeycan'da ise (8/5) olgu/ölüm görüldüğü bildirilmiştir.

Türkiye'de ise bu durumun 2006 yılında 12/ 4 kişinin ölümünün gerçekleştiği; ilerleyen dönemlerde başka olgu görülmediği bildirilmiştir. Dünya Sağlık Örgütü ise 11 Nisan 2009 tarihinde "Grip pandemisi" olarak ilan etmesine rağmen; salgının domuzlardan geçiş yapmasından dolayı "Domuz Gribi” adını alarak günümüze kadar gelmesine neden olmuştur. Ancak DSÖ'nün yapmış olduğu bir bildiride, bu virüsün genetik bir karışım olarak insan, kuş ve domuz grip virüsleri ile oluşması nedeniyle "Yeni A(H1N1)v" olarak adlandırılacağı ve Pandemik İnfluenza H1N1 salgınının dünya üzerinde son 50 yılın en önemli salgını olarak tarihe geçeceği bildirilmiştir (Şanlı, 2010:6-9).

\subsection{Veba}

Tüm dünya'da 2500 yıldan bu yana salgınlar yapmakta olan veba hastalığ1, neredeyse bütün salgınların simgesi olarak görülmektedir. Veba hastalığına neden olan patojenin Yersinia Pestis olduğu ve veba salgınlarına neden olduğu görülmüsstür. Yersinia Pestis ismi 1894 yılında Hong Kong'daki salgın sırasında Fransız bilim adamı Dr. Alexander Yersin tarafından verildiği ifade edilmiştir. Dr. Alexander Yersin tarafından oluşturulan bir araştırma ekibi, Çin'den kaynaklı olduğu düşünülen bu patojenin tespiti için İsveç’te bulunan bir mezarlığ incelemiştir. İncelemeler sonucunda vebaya neden olan bakteri tespit edince; bu bakterinin Avrupa'dan Asya'ya taşındığ görüşünü ortaya çıkarmıştır. Bulaşma yolları için ise Yersinia pestisin doğal bulunduğu canlı, marmot adı verilen dağ faresi olmuştur. Bu bakteri, bübonik, pnömonik ve septisemik veba olmak 
üzere üç formda hastalığa yol açarak insana bulaştıktan sonra öksürük ve hapşırık yoluyla insandan insana bulaşma olması ike salgının çok daha hızlı yayıldığını tespit etmiştir (Yang\& Anisimov, 2016:32-34).

Kara Ölüm olarakta bilinen veba, insanllk tarihi boyunca en fazla ölüme neden olan salgın hastalık olmuştur. Hızlı yayılan bulaşıcılığının yanı sıra tedavi edilmeyen vakalarda neredeyse $\% 100$ öldürücü olabildiği belirlenmiştir. Bu nedenle insanlık tarihinde benzeri olmayan veba salgının 6.yüzyılda Doğu Roma İmparatorluğunun başkenti olan Constantinople'de günümüzde Türkiye'nin büyükşehirlerinden biri olan İstanbul'da etkili olan ve günde yaklaşık 5000 kişinin ölümüne neden olduğu veba salgını gösterilmektedir. Bu bölgede veba salgının hızla yayılmasında bölgenin iç ve dış göçlere açık olması ve ticaret rotası olması da büyük önem arz etmiştir (Sirman, 2020 :41). Tarih boyunca pandemi olarak belirtilen üç büyük veba salgını ise sırasıyla şu şekilde sıralanabilir: 6.yüzyıl Mısır ve Suriye'de görülen Justinian Vebası; 1332 yılında Çin'den başlayarak Asya, Avrupa ve Afrika kıtalarına yayılan Kara Veba salgını ve 19.yüzyılda Hindistan'ın Bombay kentinde başladığı bildirilen veba salgınları olarak sayılmaktadır (Kılıç, 2004: s. 19).

M.S. 541 ile 750 yılı arasındaki Justinianus vebası diğer salgınların çoğunda görüldüğü gibi göçler ve ticaret yolları ile yayılarak salgınların en tehlikelisi haline gelmiştir. Bu vebanın Orta Asya ülkeleriyle Çin bölgesinde bulunan Yersinia pestis ile ilişkili olduğunu da ortaya koymuştur. Bu veba salgını iki yüzyıl boyunca 30-50 milyon arası insanın -dünya nüfusunun \%18-36'sına denk gelenölümüne yol açtığı belirtilmiştir. Ayrıca veba'nın Afrika ve Ortadoğu coğrafyasından Avrupa'ya yapılan göçler ile özellikle Cenovalı denizcilerin ticaret gemileri aracılığıyla hastalığın taşındığı belirtilmiştir (Sirman, 2020:41).

\subsection{Tüberküloz (Verem)}

Halk sağlığını etkileyen bulaşıcı hastalıkların hem yerel hem de importe vakalar (yurtdışı kaynaklı) ile gerçekleşebildiği; importe vakaların yalnızca ticaret ve turizm gibi yollarla değil; aynı zamanda göç yollarıyla da gelebildiği tespit edilmiştir. Bu hastalıklardan biri olan tüberküloz (verem) hem göçmenleri hem de hedef ülkedeki yerel halkı hızla enfekte edebilmektedir. Göçmenler içerisinde ise en riskli grubun, kamp dışında yaşayan veya kaçak yollarla düzensiz göç yapan özellikle Avrupa'ya- sığınmacıların, kaçak gemiler ve diğer taşıtlar içinde yetersiz havalandırma ve aşırı kalabalıklarla yolculuk yapmaları, beslenme ve barınma koşullarının yetersizliği, mevcut sağlık sorunları ve temizlik bilincinin olmaması ile sosyoekonomik problemler tüberküloz riskini büyük ölçüde artırmaktadır (Çalışır, 2016:6).

AFAD (2014)'e göre; genel olarak göç eden topluluklarda belirlenen en yaygın ölüm nedenleri: sıtma, ishal, pnömoni (zatürre) olmaktadır. Afrika'da ise ölümlerin \%30'u sitma hastalığından olmakla birlikte; tüm mülteci kamplarının ortak ciddi sağlık sorunlarından birinin aktif tüberküloz salgınlarının oluşturduğu bildirilmiştir. Ayrıca göç kamplarında yaşayan grupların \%40'ının ishalden öldüğü dile getirilmiştir. Çocuk sağlığı açısından en önemli konu olan Çocuk felci (Polio) ise; 2011 yılında başlayan Suriye iç savaşından önce nüfusun \%90'ına yapılan polio aşılama oranının; savaş süresince özellikle 2012 yılında \%68 oranına düşmesine neden olmuştur. Kitlesel göçler ile oluşan salgın için uygun ortamların (kötü hijyen, malnutrisyon, kalabalık) etkisiyle aşı ile önlenebilir hastalıkların önemi belirgin olarak görülmektedir. Aşılama ile ilgili hastalıklar konusunda Türkiye'nin destek vermesi ile 2018 yılı sonrası 2 yılda 3 milyon çocuk aşılanmıştır. Bu durum, Suriye'de çocuk bağışıklıklık durumunun yeniden \%85'e çıkmasını sağlamıştır (Doğruyol, 2007).

Tüberküloz hastalığı, Suriye'nin savaş öncesi döneminde 23/100 000; 2014 yılında 3470 seviyesinde olduğu bildirilmiştir. Suriye'ye komşu ülkeler olan Lübnan'da 2012 y1lında \%27; Ürdün'de 2015 yılında \%22 artırmıştır. Bu durum, tüberküloz vaka artışını veolası salgının önlenmesi için tedavi süreci boyunca kalması gerektiğini göstermektedir. Fakat, dönemin kaos ortamından dolayı can güvenliği tehlikesi ile başka bir yere göç etmek zorunda kalan hastaların tedavileri de devam edememektedir (Doğruyol, 2007). 


\subsection{Kızamık}

Türkiye Sağlık Bakanlığg (2017) faaliyet raporu verilerine göre; kızamık vakaları 2013 yılından itibaren hızla artış göstermiş olmasına rağmen; aktif bağışıklık sağlama amacıyla başlatılan aşılama kampanyaları ile 2017 yılı sonrası dönemlerde düşüşe geçmesini sağlamıştır. Özellikle Türkiye Kızamık Eliminasyon Programı faaliyetleri ile kızamık vaka sayısı 2007-2010 yılları arasında sayıca 10'u geçmemesi buna örnek olarak gösterilmektedir. Fakat 2011 yılında başlayan Suriyeli kitlesel göçleri ile bu vaka sayısında artış gözlenmiş ve kızamığın artık salgın boyutuna geçmiş olduğu bildirilmiştir. Bu belirgin artışın salgına neden olmayacak düzeyde olduğunu ve vakaların importe vakalar olduğu dile getirilmiştir. Ayrıca göçmen gruplarının izinsiz ve kontrolsüz hareket etmeleri sonucu kamp dışındaki yerlere hastalık götürebildiği ve yerel halkı enfekte edebilecek tehlikede olduğunu göstermiştir.

Kamplardaki sağlık hizmetlerinin düzenli olarak aşılama yapması sonucu bağışıklık kazanan başta bebek ve çocukların, kamp dışındaki yerlerde aşılama yaptırmamaları nedeniyle çocuklarda hastalık riskinin arttığı ve toplum sağlığı içinde büyük bir risk oluşturduğu görülmektedir (TC. Sağl1k Bakanlığı Seyahat Sağlığı Genelgesi, 2020). Kızamık vakalarının göç ile birlikte artış gösterme sebeplerinden biri de bu düzensiz ve kontrolsüz göç gruplarının varlığı olarak sayılmaktadır. Buna örnek olarak 2018 yılında DSÖ’nün Kızamık bildirimleri raporunda yayınlanan göç grupları arasındaki kızamık olgularının \%72'sinin 10 yaşın altındaki çocuklarda görülmesi gösterilebilir (Sezen vd., $2018: 122$ ).

\section{8. Çocuk Felci (Poliomyelit)}

Çocuk felci, poliovirüsün sebep olduğu ölümle sonuçlanabilen ciddi bir hastalık olarak tanımlanmaktadır. Bulaşıcı hastalıklar kategorisine giren virüs, hızlı yayılım göstererek kişiler arasında geçişi kolay olan bir zincirleme reaksiyona neden olabilmektedir. Kişinin omuriliğini tutarak enfekte eden bu virus, felç yapma özelliğine sahip şiddetli bir semptomatik hastalık olması nedeniyle kalıcı sakatlığa ve ölüme yol açabilmektedir. Buna örnek olarak Poliovirus enfeksiyonu nedeniyle felç olan her 100 kişiden 2'sinde ölümle sonuçlanması gösterilebilmektedir. Ayrıca enfekte kişinin boğazında ve bağırsaklarında yaşayarak parazitlerin -özellikle dışkı ve solunum yolu aracılığıyla- temasta bulunduğu kişilere geçirdiği belirtilmektedir. Bu hastalığı önleyici iki tip aş1 geliştirilmiş olup bu aşılar şu şekilde belirtilmiştir.

1. İnaktive edilmiş poliovirus aşısı (IPV), hastalığ belirlenmiş kişinin yaş duruma göre bacak veya kol bölgesinden enjeksiyon yapılmaktadır.

2. Oral poliovirus aşısı (OPV) ise, günümüzde tüm dünya tarafından kullanılan aşı olmaktadır. Ancak 2000 yılından günümüze değin Amerika Birleşik Devletleri yalnızca IPV'yi kullanılmaktadır (CDC, 2019).

Sezen vd. (2018)' göre; ulusal sağlık güvenliğini riske atabilecek olası bir çocuk felci salgının oluşmasını önlemek için Batı Şeria, Gazze Şeridi, Irak, Lübnan, Mısır, Suriye, Türkiye ve Ürdün acil müdahale kapsamında yer alan "yedi ülke-yedi bölge" olarak belirtilmiştir. Bunun nedeni olarak ülkelerin jeopolitik konumları ve ülkelerin sağlı yetersizlikleri baz alınmış; bu bağlamında virüsün yayılımının yükseleceği öngörüsü oluşturulmuştur. Göçler ile bulaş yolu bulan çocuk felci virüsünün Dünya Sağlık Örgütü (2018) tarihli raporunda 2018 yılında Suriye'den gelen hiçbir çocuk felci vakasının bulunmadığını belirtmiştir. Ayrıca savaş bölgelerinde ve kamplarda artan kızamık salgınlarını önlemek amacıyla DSÖ ve Türkiye'nin de aralarında olduğu "sağlıkta işbirliği" başlığı altında ülkelerin eşzamanlı yapacağı çocuk felci ve kızamık aşılama kampanyası başlatılmasına karar verilmiştir.

Türkiye'nin en yoğun nüfusuna sahip göç kamplarında başlatılan aşılama kampanyası için başta Gaziantep merkez olmak üzere çalışmalara başlanmıştır. Türkiye, DSÖ ve Suriye Bağışıklama Grubu önderliğinde yaklaşık 1200 aşılama ekibi ile birlikte 764.550 çocuğun çocuk felcine karş1

Turkish Studies, 15(4) 
aşılanmasını hedefleyen kampanyayı başlatarak; aşılamanın ilk 2 turunun İdlib ve Halep, Humus ve Hama'nın belirlenen bazı bölgelerinde yapılması kararlaştırılmıştır. Bu bölgelerdeki ve Türkiye'deki 5 yaş altı çocuklara oral çocuk felci aşısı (OPV) ve A vitamini verilerek, virüsün direnme ve bulaşı önleme yeteneklerini arttırması düşünülmüştür. Ayrıca Türkiye'ye düzensiz göç ile gelen her 0-15 yaş grubu çocukların da bu aşılamaya tabii tutulmaya ve her 9 ay- 15 yaş arasındaki çocuğa kızamık aşısı yaptırılması imkânı verilmiştir. Ayrıca infeksiyon -bulaşıcı- hastalıkların salgın boyutuna ulaştığ 1 yerlerde 6-12 aylık bebekler için ek doz yaptırılmasına karar verilmiştir. Ancak bu aşıların zorunlu olmayışı ve aşı karşıtlığı gibi düşüncelerin aşılama kampanyasının verimini düşürdüğü öne sürülmüştür (T.C. Sağlık Bakanlığı, 2015).

\subsection{HIV + / AIDS}

İnsan Bağışıklık Yetmezliği Virüsü (Human Immunodeficiency virüs, HIV), insan rezervuarında bağışıklık sisteminin zayıflamasına neden olan bir virüsün etkisi olarak tanımlanmaktadır. AIDS (Acquired Immunodeficiency Syndrome, Edinilmiş Bağışıklık Yetersizliği Sendromu) ise HIV enfeksiyonunun bağışıklık sistemi üzerindeki zayıflatma seviyesinin daha ileri düzeye geçtiği ve bu hastalığa özgü belirtilerin başladığını gösteren süreci ifade etmektedir. Lentivirinae alt ailesinden zarflı bir retrovirüs olan HIV; bağışıklık sistemini zayıflatması sonucu kronik bir enfeksiyon hastalığına yol açarak AIDS tablosu ile ölümle sonuçlanabilen bir süreci başlatmaktadır (HSGM, 2019). Bu hastalık, günümüzde tüm dünyada yaygın olarak görülmekle birlikte; gelişen teknoloji ve tıbbın ilerlemesi sayesinde bazı vaka gruplarında geçmiş tarihe oranla, daha kontrollü tedavi edilmesine olanak sağlamıştır. AIDS, günümüzde ilaçların doğru ve düzenli kullanımı ile ölümle sonuçlanmadan kontrol altına alınabilen fakat yaşam boyu ilaç kullanımı gerektiren bir hastalığa dönüşmüştür. Ayrıca Türkiye'de HIV/AIDS ve cinsel yolla bulaşan diğer enfeksiyonlar önleme ve tedavi sağlama hedefiyle Ulusal AIDS Komisyonu (UAK) kurulmuş, küresel hedeflere dair yeni bir Türkiye HIV/AIDS Kontrol Programı oluşturulmuştur (T.C. Sağlık Bakanlığı, 1996).

HIV/AIDS hastalığının tüm dünyada yayılımının kolay olduğu en riskli gruplar; sağlıksız cinsel davranış öyküsü bulunan çiftler, çok sık kan transferi yaptıran kişiler, uyuşturucu madde kullanımı olan gruplar, ceza infaz kurumlarında bulunan mahkumlar, göçmenler ve savaş, afet, salgın hastalıklar gibi ortamlardan kaçan mülteciler, barınma ve beslenme düzenleri olmayan kişiler ve evsizler, yüksek riskli gruplar ile çalışan sağlık çalışanları yüksek riskli olmaktadır. 2019 yılı itibariyle dünya üzerinde yaklaşık 36,9 milyon kişinin vücudunda HIV virüsü bulunduğu ve bu hastalıkla yaşamına devam ettiği bildirilmiştir. Bu oranın, Doğu Avrupa ve Orta Asya ülkelerinde sağlık istatistikleri yıllı̆̆ına göre gün geçtikçe yeni enfeksiyon tanıları ile hızla artmaya devam ettiği görülmektedir. (HSGM, 2019:10).

Göçmenlerin ise; HIV/AIDS bildirilen vaka oranları arasında büyük bir orana sahip olduğu tespit edilmiştir. $\mathrm{Bu}$ doğrultuda göçmenlere yönelik sağlık hizmetleri çalışmalarını geliştirmek hedefiyle; Geçici barınma kampları ile insani yardım kuruluşlarında çalışan kişilerin, göçmenler arasındaki vakaları mahremiyet ilkeleri kapsamında bildiriminin yapılması talep edilmiştir. Böylece halk sağlı̆̆ının korunması ve sağlık hakkının sağlanması zorunlu tutulmuştur. T.C. Sağlık Bakanlığı Temel Sağlık Hizmetleri Genel Müdürlüğü 2008 / 14 sayılı Genişletilmiş Bağış̧ılama Programı Genelgesi ve ilgili çalışmaların prosedürleri ve yapılacaklar listesi geçici barınma (göçmen) kampları dahil tüm sağlı kurumlarına gönderilmiş ve tüm sağlı personelini bağlayıcı kriterlerine uyulması zorunluluğu olduğu belirtilmiştir (UNFPA, 2018).

\subsection{Sitma}

Sitma, tarih boyunca uygarlıkların ve imparatorlukların yıkılmasında önemli bir hastalık olmuştur. Toplumlara bulaşıcı hastalıkların birtakım böcek veya diğer vektörler aracılığıyla geçebileceğini, büyük yıkımlara neden olabileceği öğretmiştir. Bu sayede toplumlar vektörlerle bulaşan hastalıkların önlenmesi, bulaş yollarının kontrol edilmesi ve tedavisinin bulunması için bazı 
yöntemler geliştirmesini sağlamıştır. $\mathrm{Bu}$ endemik veya epidemik hastalıklar arasında ise; sarıhumma, tifüs, uyuz gibi bulaşıcı hastalıklar sayılmaktadır. Sıtma hastalığının bataklık ve durgun su birikintilerinde meydana geldiğini öğrenen toplumlar; temiz su ve çevre yaşamının önemini anlamış ve çevre sağlığına dair gelişmelerin sağlanmasına öncülük etmiştir. Bu amaçla sıtma yatağı olan bölgelerin çevre izolasyonu sağlanarak; sıtma eradikasyonu yapılması amacıyla çalışmalara başlanmıştır. Özellikle tarım ve sağlı ilişkisinin kurulması yönünden ilaçlama, sulama, yol yapımı vb. gibi çalışmaların istikrarı günümüzde halen faaliyetlerine devam etmektedir (Eren, 1989:63).

Ata (2013)' göre; Türkiye'nin iklim koşulları sıtma vektörünün gelişimi için uygun olmaktadır. Bunun nedenleri ise şu şekilde sıralanmıştır.

a. İklim ve çevre şartları,

b. Toplumların yaşam biçimleri ve alışkanlıkları,

c. Vektör aktivitesinin özellikleri,

d. Göçler olarak sayılmaktadır. Bu kriterler sıtma salgını için uygun şartların oluşumuna katkıda bulunmaktadır.

Buna ek olarak; sıtmanın yaygınlığg iklim değişikleri ve insan hareketliliği, göçler nedeniyle değişmektedir. Türlerine göre yaygınlık durumları ise şu şekildedir:

- $\quad$ P. falciparum dünyada en yaygin tür,

- P. vivax Afrika dışında dünyada en yaygın,

- P. ovale Sub-sahra Afrika,

- P. malaria Güney Amerika, Asya ve Afrika'da,

- $\quad$ P. knowlesii Güneydoğu Asya'da yaygın olarak görülmektedir (Ata, 2013:8).

DSÖ (2013) raporuna göre; 2013 yılı itibariyle 97 ülkede 3.2 milyar kişide sıtma bulaş riski bulunmaktadır. Ayrıca tahmini 1.2 milyar kişinin yüksek risk altında olduğunu -1000 kişide $>1$ - kişi ve 2013 yllında 198 milyon kişide 584.000 ölüm olduğu bildirilmiştir. Bu ölüm oranlarının ise \%90'ının Afrika'da gerçekleştiğini; bu oran içindeki \%78'inin 5 yaş altı çocuklarda ve göçmenlerde meydana geldiği belirtilmiştir.

\subsection{1. Çiçek}

Çiçek hastalığı, insanlık tarihinin en eski ve en tehlikeli bulaşıcı hastalıklardan birisi olmaktadır. Ancak tüm dünya tarafından uygulanan eradikasyon uygulamaları neticesinde, aşı ile önlenebilir çalışmalara dahil edilerek; yeryüzünden kaldırılan ilk salgın hastalık olması nedeniyle tarihe geçtiği bilinmektedir. Tarihte ilk kez M.S. 900 yılında İslam Hekimi Razi tarafından çiçek hastalığ 1 tanımı yapılmış; hastalığın sıklıkla doğu ülkeleri arasında yaygın olduğunu belirtilmiştir. Buna ilaveten Ortaçağ döneminde meydana gelen büyük veba salgının çiçek hastalığından dolayı ortaya çıktığını belirtmiştir. Bu sav'a başka bir örnek olarak M. S. 189'daki Roma Salgını ile 302'deki Suriye'de meydana gelen çiçek salgını vakası gösterilebilmektedir. Bu durum çiçek hastalığının bir Orta doğu bölgesi hastalığı olduğunu; bu hastalığın Avrupa'ya taşınmasının ise Haçlı ordularının savaşlar sonucu ülkelerine taşındığını ortaya çıkarmıştır. Tarihte çiçek salgınlarının ölüm oranları ise şu şekildedir:

- $\quad$ XVIII'inci yüzy1l Avrupa'sında 60 milyon kişinin

- $\quad$ Fransa'nın Paris şehrinde bir yılda 14 bin kişinin öldüğü,

- $\quad$ Almanya'da her sene yaklaşık 30 bin kişinin çiçekten öldüğü, 
- İ̇landa'da meydana gelen çiçek salgınında nüfusun yüzde 40'ını öldürdüğü,

- Londra'da 1760-1770 yılları arasında tüm hastalıklardan ölen toplam sayısının 234.412 olmasına karşın; sadece çiçek salgınından ölenlerin sayısının 24.234 kişi olduğu tespit edilmiştir (Eren, 1989:72).

İlk kez M.Ö.10.000 yıllarında Çin'de ortaya çıktığı düşünülen çiçek hastalığının özellikle çiftçi toplulukların yoğun olduğu bölgelerde meydana geldiği bildirilmiştir. Kesin bilinmemekle birlikte Çin'de başlayarak tüm dünya'ya yaılan çiçek hatalığının ilerleyen dönemlerde savaş ve göçlerle hızlandığı belirtilmiştir. Bu doğrultuda tarihte bilinen büyük çiçek salgınlarının savaş ortamlarıyla ilişkilisine verilecek örneklerden bazıları sırasıyla; M.S. 161 yılında Roma İmparatorluğu'nun savaş seferine çıkması üzerine başlayan çiçek hastalığı; 18.yüzyıl Kuzey Amerika kıtasına yine savaş ve göçler sonucu Kızılderililere çiçek hastalığı bulaştırması savaş, göç ve çiçek hastalığı ilişkisini ortaya çıkarmaktadır (Kılıç, 2004:36).

\subsection{Kolera ve Tifo}

Kolera hastalığı; vibrio cholerae bakterisinin ince bağırsakta oluşturduğu enfeksiyon olarak tanımlanmaktadır. Buna ilaveten doğal afetlerden etkilenen ve savaş ortamında bulunan toplumlarla yoksul gruplarda kolayca yayılarak ölümcül sonuçlara neden olmaktadır. Günümüzde her yıl gelişmekte olan ülkelerde tahmini 3-5 milyon kolera vakası tespit edilmekte; bu vakaların ise yaklaşık 100 bininin ölümle sonuçlandığı belirtilmektedir. Bulaşıcı bir hastalık olan kolera, sadece insanlarda görülmekle birlikte gelişmekte olan ülkelerde daha tehlikeli bir halk sağllğg sorunu olmaktadır. Özellikle mültecilerde ve kitlesel göçlerde, kolera hastalığına yakalanma riski 2 kat daha hızlı yayılmaktadır. Göç kamplarının ve göç yollarının kurak ve çöllerle kaplı olmasına ek olarak yaz aylarına denk gelmesi kolera salgını riskini daha çok arttırmaktadır (Medicalpark, 2020).

DSÖ (2015)'in 2015 yılında Kolera ile göç ilişkisinin anlaşılmasına yönelik yapılan bir saha çalışmasında Suriye'nin Halep bölgesinde yaşayan 5 yaşında bir çocuğun şiddetli sulu ishal nedeniyle ölümünün meydana geldiği bildirilmiştir. Buna ek olarak, DSÖ'nün Irak Sağllk Bakanlığı'nca yayınladığı (2015) raporuna göre; Irak'ın bazı ilçelerinde kolera vakalarının görüldüğünü ve bu vakaların hızla artarak salgın boyutuna geçtiği resmi olarak açıklanmıştır. Bu salgının, Irak'a sınır komşusu olan ülkelere de yayılmaması için acil eylem planının hazırlandığını; yayılım hızının artması halinde bu eylem planının hayata geçirileceği belirtilmiştir. Ayrıca DSÖ tarafından bu raporda Suriye'deki iç karışıklık ve savaş ortamı nedeniyle büyük kitlesel göçlerin artmasının Irak'ta meydana gelen kolera salgınının oluşmasına ve yayılmasına hızla etki ettiği ve akabinde Türkiye'nin de bu salgından ciddi oranda etkilenme riskine sahip olduğu iddia edilmiştir. Bu hipotez doğrultusunda Türkiye Sağlık Bakanlığ 1 aldığı bir kararla Türkiye'nin güney bölgelerinde görevlendirilmek üzere -göçmen nüfusun yoğun olduğu bölgeler olması nedeniyle- bilimsel kurula sunulmak üzere göç ve hastalık ilişkisi konusunda detaylı bir araştırma raporu yapılmasını talep etmiştir.

\subsection{Koronavirüs Salgını}

Coronavirüsler, büyük bir virüs ailesi olarak hayvanlarda veya insanlarda hastalık yapıcı etkiye sahip olmakla birlikte; bu virüsün Orta Doğu Solunum Sendromu (MERS) ve Şiddetli Akut Solunum Sendromu (SARS) gibi hastalıklara da neden olduğu belirtilmiştir. Koronavirüsler, tarih boyunca HCoV-NL63, HCov-229E, HCoV-OC43 ve HCoV-HKU1 virüsleri ile hastalık yapmış olup; ek olarak SARS ise 2002 yılında Çin'in Guangdong eyaletinde başlayarak doğal rezarvuarının yarasa olması ve yarasadan vahşi kediye; oradan da insana bulaştığı tespit edilmiştir (Yücel \& Görmez, 2019:33-34).

SARS, MERS ve COVID-19 yüksek bir yayılma hızına sahip bir virüs olmakla beraber; yoğunlukla yaşlı nüfus içinde ve hipertansiyon ya da Tip2 şeker hastalığı bulunan kişilerde büyük 
risk oluşturmaktadır. COVID-19 virüsü, ACE2 reseptörlerinden hücre içine girerek çoğalmaya başlayarak immün sistemini bozmaktadır. Bu durum sitokin (Cytokine) adı verilen maddenin salgılanması ile "Sitokin firtınası sendromu" adı verilen duruma sebep olarak bugünki koronavirüs semptomlarını meydana getirmektedir. Coronavirüs salgını, DSÖ tarafindan 30 Ocak 2020 tarihinde Uluslararası Acil Durum resmen ilan edilmiş; 11 Şubat 2020 tarihinde bu yeni koronavirüs hastalığ için COVID-19 adı verilmiştir. Günümüzde halen devam eden COVID-19 nedenli koronavirüs, pandemisi, yüzyılın en büyük salgın hastalığı olarak tarihte yerini korumaya devam ettiği belirtilmektedir (WHO, 2020).

\section{Pandemilerin Antropolojik Açıdan Önemi}

Antropoloji kavramı, insanlığın tarih sahnesinde var oluşundan bu yana zaman içinde meydana gelen temel sorunlara yönelik çözümleri araştıran bir bilim dalı olmaktadır. Bu doğrultuda insanlığın geçmişi, zaman içindeki kültürel gelişimleri ve değişimleri, biyolojik formları, kitlesel göç hareketleri, endemik ve pandemilerin epidemiyolojisi, adli ve kimliklendirme çalışmaları ve günümüzdeki mevcut gelişmeler gibi pek çok çalışma ve inceleme alanı bulunmaktadır (Özkoçak \&Özdemir, 2018: 1190).

Günümüzde hemen her alanı ve bölgeyi etkileyen en önemli olayın Coronavirüs türevli COVID-19 Pandemisi olduğu belirtilmiştir. Gerek antropoloji gerek sağlık işletmeleri için ciddi değişimlere ve araştırma alanları açılmasına neden olan bu virüs, ilk olarak Çin'in Wuhan şehrinde bilinmeyen bir pnömoni vakası kümesi ile 2019 yılının sonlarında tarih sahnesine çıkmıştır. Başlangıçta COVIDD-19'un önceki yıllarda ortaya çıkan SARS ve MERS virüslerinden daha az etki yaratacağı açıklanmışsa da; hızla artan vaka sayıları ve pandemi boyutuna geçerek tüm dünyayı etkilemesi bu açıklamanın erken olduğunu göstermiştir. Böylece 2020 yılının 20 Ocak tarihinde virüsün patlak verdiği Çin devletinde yeni kararlar alınarak "Ulusal Bulaşıcı Hastalıklar Yasası" 2019-yeni koronavirüs hastalıklarını (Covid-19) B Sınıfı bildirilebilir bir hastalık haline getirecek şekilde değiştirilmiştir. Bu durum Covid-19 salgını ile önleyici müdahale çalışmalarını genişletmek amacıyla "Sınır Sağlık ve Karantina Kanunu" ile önleyici tedbirlere yeni kurallar getirilmiştir. (Özkoçak vd, 2020: 145).

Covid-19 salgınının hızla ilerleyişi karşısında başlatılan bu yeni uygulamalar, nüfus dinamiklerini düzenlemek ve yeni dünya düzenine uygun hale getirmek amaciyla antropolojik araştırmalara gereksinim arttırmıştır. Özellikle savaş ve salgın hastalıklar tipolojisi, etnik grupların kökeni, tüm dünya nüfusunun kültürel değişimin nedenleri ve diğer tüm alanlardan genişletilmiş sorular, tarih boyunca yapılan iç ve dış göçler ve diğer demografik süreçlerin incelenerek cevaplanabileceği öngörülmektedir. Tarih boyunca incelenmesi gereken tüm bu süreçlerin günümüzde yaşanılan olaylarla benzeştiği ortaya çıkmaktadır. COVID-19 Pandemisi, dünya üzerindeki hemen her canlının hayatını tehdit edebilen ve kolay yollarla bulaşabilen bir "yeni yüzyıl tehdidi" olarak nitelendirebileceğimiz bir problem olarak tarih sahnesindeki yerini almıştır (Özkoçak vd., 2020:1192).

\section{Göçlerin Toplum Sağlığı İçindeki Yeri ve Önemi}

Endemik bölgeden endemik olmayan bölgeye göç ederek yer değiştirme hareketi yapan enfekte kişi veya gruplar, vektör ve çevre koşulları uygun olduğu taktirde gittikleri bölgeye hastalık taşımaları gerçekleşebilmektedir. Buna ilaveten enfekte olmayan göçmen kişi veya gruplar, endemik bölgeye yerleşmeleri sonrasında yerli insanlarından daha fazla infeksiyon riskine sahip olabilecekleri belirtilmektedir (Klaus vd., 1999:45).

München (1994:64)'e göre;ev sahibi bir ülkede yer alma ve o ülkenin toplumunun kabul görme çabasıyla karşılaşılan sorunlara ek olarak mülteciler, istihdam ve konut bulmakta zorluklarla karşılaşmaktadır. Bireyler kendilerini yeni ortamlara, yaşam tarzlarına, değerler ve gelenekler ile ilgili yeni fikirlere ve yerel dile adapte etmek zorunda kalmaktadır. Ulusal kültürlerini kaybetme 
riskiyle karşı karşıya kalarak, özellikle kültür sözlü olduğunda ve sürekli olarak topluma uyum sağlayamama psikolojisiyle yaşamaya başlamaktadır. Sürekli artan nüfusla birlikte, daha fazla sanayileşme ve kentleşme salgın hastalıkların yayılması riskini arttırmaktadır. Etiyopya, Sudan, Mozambik ve diğer gelişmemiş/gelişmekte olan ülkelerde önlenebilir iç savaşı takip eden süreçte açlık ve yoksulluktan ölenlerin sayısının Afrika'da kuraklık etkilerinden ölenlerin sayısının yakın olduğu bildirilmiştir. Bunu takiben Zambiya ve Peru'daki ölümlere neden olan kirli suyun kullanımı ise; şehirleri büyük kolera salgınlarına sürüklemiştir. Doğal afetler ve salgınlar devletlerin sosyal sistemleri üzerinde birçok terapötik etki yaratmıştır. Savaş ve ekonomik düzensizlikler yoksul halk kesimini daha fazla etkileyerek köylü ve fakir halkın ayaklanmasına neden olmaktadır. Bu ayaklanmalar karşısında devletler hızla çözüm aramaya girmişlerdir. Özellikle bu dönem artan soygunculuk, kaçakçılık, ulusal güvenliği tehdit eden oluşumlar, çatışma ortamı, göçler ve enfeksiyon hastalıkları nedenli bulaşıcı hastalıklar ciddi problem yaratmıştır (Meuleau, 1978:1102).

Çeşitli nedenlerle yaşamını yitirmiş göçmenlere ait iskelet kalıntılarını, fiziksel özelliklerini ve karakteristik unsurlarını, anatomik ve antropometrik yapılarıyla inceleyen Adli Antropoloji ulusal güvenliği ve halk sağlığını tehdit edebilecek problemlerin çözümünde katkıda bulunmaktadır. Ayrıca mültecilerin ölüm şeklinin, zamanının ve nedeninin bulunması; aynı zamanda doğal afetler, salgın hastalıklar ve savaşlar gibi tehlikeli sürecin mağdurlarının kimliklerinin tespitinde çalışmalar yapmaktadır. Ayrıca hayatını kaybeden kişilerin tanımlanmalarında, tasnif edilmelerinde ve olay çözümlenmesinde başvurulan çok önemli katkılar sunduğu bildirilmiştir. (Taşkın vd., 2019: 3).

Günümüzde mülteci ve göçmenlerin -sığınmacı-geçici koruma dahil- sağlık kontrollerinin yapılması ve adli antropoloji ile anatomik olarak tanınması için aşı çalışmaları hızlandırılmıştır. Türkiye'de bulaşıcı hastalıkların tedavisine yönelik aşı ile bağışıklık kazandırılması çalışmaları için aşı takvimi oluşturulmaktadır. T.C. Sağlık Bakanlığı'nın öncülügünde ücretsiz olarak yapılan ve reçetelendirilme kararı kapsamında Grip ve Pnömokok aşısının (riskli gruplar, kronik hastalar ve yaşlılar, gebeler) tanı-tedavi sonrası devlet tarafından ödemesi sağlanmaktadır. Bu doğrultuda "T.C. Sağllk Bakanlı̆̆l ve Bağll Kuruluşlarının Teşkilat ve Görevleri Hakkında Kanun Hükmünde Kararname" 663 sayılı kararla 02.11.2011 tarihli 28103 sayılı düzenleme ile Sağlık Bakanlığı ve bakanlığa bağlı kuruluşlarının yeniden yapılandırılmasına karar verilmiştir. Ayrıca 06.04.2011 tarihli ve 6223 sayılı yasanın verdiği hüküm gereğince, T.C. Bakanlar Kurulu tarafindan 11.10.2011'de kararlaştırılan kararnamenin 26/c maddesi şu şekildedir:

"Bulaşıcı, bulaşıcı olmayan, kronik hastalıklar ve kanser ile anne, çocuk, ergen, yaşlı ve engelli gibi risk gruplarıyla ilgili olarak izleme, sürveyans, inceleme, araştırma, bağışılklama ve kontrol çalışmaları yapmak, bununla ilgili verilerin toplanmasını sağlamak, belirlenen hedefler doğrultusunda plan ve programlar hazırlamak, uygulamaya koymak, denetlenmesini sağlamak, değerlendirmek, gerekli önlemleri almak, bu konuda politika ve düzenlemelerin oluşturulması için Bakanlığa teklifte bulunmak, Sağlık Bakanlığı Halk Sağlığı Genel Müdürlüğüne görev olarak verilmiştir. Ayrıca, 3359 sayılı Sağlık Hizmetleri Temel Kanunu (RG 15.05.1987, sayı 19461) md. 3/k ile de Sağlık Bakanlığına aşılarla ilgili dolaylı görev ve yetki verilmektedir".

Dünya Sağlık Örgütü'nün 1988 yılında verdiği karar ile Poliomyelitin 2000 y1lına kadar eradike edilmesi hedeflenmiştir. Böylece tüm dünyada eradike edilen çiçek hastalığından sonra eradikasyon hedefi belirlenen ikinci hastalık poliomyelit olmuştur. Bu doğrultuda 1989 yılında yürütülmeye başlanılan Poliomyelit Eradikasyon Programı (PEP) ve programın bir parçası niteliğinde olan Ulusal Aşı Günleri (UAG) çalışmaları başlamıştır. Eradikasyon hedefi doğrultusunda transmisyonunun durdurulması çalışmaları -Türkiye de dahil olmak üzereuygulamaya geçirilmiştir. Poliomyelitin eradikasyonu amaciyla 4 stratejik hedef belirlenmiştir. Bunlar sırasıyla şu şekildedir:

- Rutin aşılama çalışmalarının güncelleştirilip geliştirilmesi ile OPV3 aşılama oranının \%90'ın üstüne kadar çıkartılması ve aşılamaların sürdürülmesi, 
- $\quad$ Ulusal Aşı Günleri’nin devam ettirilmesi,

- $\quad$ Akut flask paralizi ve vahşi poliomyelit sürveyansının sağlanması, Pekşen, 2000:213).

Mopping-up çalışmalarının hızlandırılması şeklinde belirlenmiştir (Canbaz \&

Dünya Sağlık Örgütü'nün bu 4 strateji doğrultusunda bulaşıcı hastalıklarla mücadele amacıyla -Poliomyelit dahil- Genişletilmiş Bağışıklama Programı ile aşı ile önlenebilir hastalıklardan çocuk gruplarını korumak veya bağışıklık kazandırmak amaçlanmıştır. Özellikle savaş, kıtlık, su kaynaklarının azlığı, bilinçsiz topluluklar ve göçmenlerin yoğun olduğu fakir bölgelerde aşılama oranlarını arttırarak riski en az seviyeye indirmenin önemi günümüzde görülmektedir. Türkiye'nin jeopolitik konumu gereği Avrupa, Asya ve Orta doğu kıtaları ile komşu olması, polio vakalarının endemik olduğu ülkelere yakınlığı ve bu bölgelerden yapılan göçler, Türkiye'ye virusun geçişini kolaylaştıracak bir tehlike olarak görülmektedir (Orhon, 2020:11). Polio eradikasyon çalışmalarının sınırlarda ve kamplarda hızlandırılması ulusal güvenlik ve halk sağlı̆̆ı bu açıdan da büyük önem arz etmektedir. 1998 yılında Türkiye'nin Ağrı ilinde vahşi poliovirus vakasının rastlanması sonucu hızlandırılmış bağışıklama programları ile 2002 yılında eradikasyon sağlandığının belgelenmesi ile önemli bir adım atılmıştır. Bu sonuç Türkiye'nin son yerli vahşi poliovirus vakasının eradike edildiğini göstermiştir. Bu duruma benzer şekilde Suriye'de en son 1999 y1lında görülen poliovirus vakasının 2011 yılında başlayan Suriye iç karışıklıkları ve savaş ortamı ile Polio3 doz aşılamalarının azalması sonucu 2013 yılında 35 Polio vakası görülmesine yol açmıştır. Böylece Suriye'de savaş öncesi dönemde $\% 90$ olarak bildirilen polio aşılama oranının savaşın başlaması ile birlikte -2012 yılı verilerine göre- \%68 seviyesine kadar hızla gerilediğini göstermektedir (Eskiocak \& Marangoz, 2018:123).

Suriye'de savaş ortamlarından kaçarak göç eden kitleler arasında göç olgusunun getirdiği sorunların etkisi ile vahşi tip 1 polio virüsün hızla yayılarak enfekte etme riski ekseriyetle önem arz etmektedir. Suriye, Irak ve İran'dan göç kitlelerinin jeopolitik sınırlar gereği Türkiye’ye doğru hareket etmeleri ile bu riskli ülkelerde görülen polio virüsünün hem düzensiz göçmenlerin göç rotaları üzerinde; hem varış yerlerinde bağışıklık çalışmaları yapılmasını gerekli kılmaktadır. Bu duruma örnek olarak; 2012 y1lında Suriye'de ve 2013 yılında Irak'ta patlak veren Çocuk Felci salgınları verilmektedir. Başta Ortadoğu ve Afrika kıtası gibi bölgelerde yaşanan sağlık problemleri, savaş ortamları, kıtlık gibi durumlardan doğan polio salgınları devletlerin sağlı politikaları ile doğrudan ilişkilidir. Çünkü devletlerin bulaşıcı hastalıkları önleyici ve yayılımlarını durdurucu çalışmaları, ülkelerin sürveyans sistemleri ile fire vermeden yeterli aşılama sağlanması ile önlenebileceği öngörülmektedir. Buna ilaveten göç kampları ve göç rotalarındaki yaşam koşulları da düşünüldüğünde; bu çalışmaların öncelikli alanların bu alanlar olduğu ortaya çıkmaktadır. Zira salgının başladığı sürecin hızla yayılması -Türkiye dahil- tüm dünya, ülke sınırlardan başlayarak il il tüm bölgelerde polio importasyonuna karşı aşılama ve kapasite geliştirici faaliyetler yürütmesi gerekliliğini göstermektedir (UNICEF, 2014).

\section{Tartışma}

Hussain vd. (2003)'nın TBC'nin prevalansını Pakistan'da bir eyaletteki mahkumlar üzerinde bir çalışma yapmıştır. Bu çalışmaya göre; cilt testleri ve balgam smearları enfeksiyon derecesini tanımlamıştır. Mahkumlar arasında enfeksiyon riski arasında anlamlı bir ilişki bulunmuştu. Ancak uzun süreli mahkumların kaldığı alanların aşırı kalabalıklaşma, eğitim ve halk sağlığının azalmasının önüne geçebilmek için her mahkûmun rutin olarak taranması, aktif veya latent TB tanısı için balgam smear ve cilt testleri klinik veya profilaktik tedavi yapılması ön görülmüştür.

Savaş, Göç ve Sağlık Çalıştay’1 (2017) raporunda savaşlar ve göçler ile iç içe gelişen bulaşıcı hastalıkların özellikle kronik rahatsızlığı olanlar, yaralılar ve işkenceye maruz kalanlar, engelliler, şiddet travması geçiren ve bağışıklık sistemi düşük yaşlılar, aşırı yoksul aileler, tek yaşayan kadınlar 
ve gebeler üzerinde etkisinin risk derecesinde olduğu; HSGM Bulaşıcı Hastalıklarla Mücadele Rehberi (2017)'in belirttiğine göre ise; resmi kayıtları olmayan göçmenler ve kamp ortamında yaşayan gruplar özel sağlık sistemi enfeksiyon hastalıklarına karşı dikkate alınmalıdır. Buna neden olarak savaş ve göç ortamlarının gerek ekolojik ve çevresel nedenlerle gerek toplumun beslenme, barınma, sağlık hizmetlerine erişim ve yasa dışı göç yollarının zorluğu gibi nedenlerin insan ve toplum sağlı̆̆ 1 üzerindeki kötü etkileri gösterilmiştir.

Özkoçak vd. (2020)'nin “Pandemilere Antropolojik Bakış: Koronavirüs (Covid-19) Örneği” çalışmasında COVID-19 süreci ile birlikte artık yeni bir dünya düzeninin oluşacağını ve küreselleşme boyutu ile ülkelerarası sınırların kalktığına dair bazı görüşlerin aksine,pandemilerin ülkelerin kendi sınırları içerisinde ulusal mücadele programlarını uygulamayı tercih ettiklerini fakat tüm dünya için bir tehdit boyutuna geçen salgın hastalıklara karşı herkesin denetimli uyum içerisinde yaşamas1 gerektiğini belirtmiştir. (Özkoçak vd., 2020:1193).

WHO (2018)'in “Küresel Ölümlerin İlk 10 Nedeni” çalışmasında, gelişmemiş ve gelişmekte olan ülkelerde veya geliri düşük topluluklarda ölümlerin yarısından fazlası, bulaşıcı hastalıklardan, gebe-anne-doğum sürecinin koşullarından ve beslenme yetersizliklerinden olmaktadır. $\mathrm{Bu}$ durum incelendiğinde, ülkelerin, mortalite ve morbidite sayısı veya oranı, o ülkenin sağlık sisteminin etkililiğini değerlendirmek açısından önem arz etmektedir. Ölçülen ölüm nedenli istatistikler aracılığı ile gerek sağlık politikaları gerek sağlık çalışanlarının halk sağlığı konusundaki faaliyetleri belirlenmektedir.

\section{Sonuc}

Uluslararası göç olgusu, tarih boyu uygarlıklar, imparatorluklar, yönetim sistemleri, toplum düzeni, savaşlar ve hastalıklarla doğrudan ilişkili bir yapı olarak günümüze değin ciddiyetini koruyan bir oldu olmuştur. Dünya üzerinde çağ atlanmasında dahi büyük etkisi olan göç olgusu, 21.yy'ın değişen yaşam koşulları nedeniyle kabuk değiştirmiş; yeni göç modelleri ve göçmen sınıflarının oluşmasına neden olmuştur. Göçlerin neden ve sonuçlarının farklı disiplinler olarak toplumlara hatta küresel alana etkileri ayrı incelenmekle birlikte; bu yer değiştirmelerin neden olduğu savaşların sonuçlardan biri olan salgın hastalıklar, cephede ölen askerlerin ve dahi sivillerin sayısından daha fazlasının ölümüne neden olduğu tespit edilmiştir. Bu hastalıkların belli başlıları ise sırasıyla; İnfluenza, İspanyol gribi ve kuş gribi salgınları, skorbüt vakaları ile çocuk felci (polio) salgınları, veba, verem (tüberküloz), kızamık, çiçek, frengi, HIV (+)/AIDS, sıtma, tifüs, cüzzam, kolera ve tifo, şark çıbanı olarak sayılmış olup endemik oldukları bölgelerin ortak olarak kirli ve hijyenik olmayan yaşam ortamlarında ortaya çıktığını, nüfus artışının veya kalabalık yaşamın olduğu yerlerde hızla yayıldığını, bir yerden başka yere geçiş yapan kişi veya gruplarca taşındığının, aşılamanın yapılmadığı taktirde ölümle sonuçlanabildiğini ve her türlü göç biçimlerinin bulaşıcı hastalıklarla yakından ilişkili olduğu görülmüştür.

Çeşitli şekillerde ve farklı nedenlerle ortaya çıkan enfeksiyon hastalıklarının yalnızca ortaya çıktığı toplumu değil; artık tüm dünyayı etkilediği ve büyük yıkımlara yol açtığı görülmüştür. Bu etkilerin ise sadece halk sağlı̆̆ı konusunda olmayıp devletlerin yönetim şekillerinden kültürel ve dini formlarına kadar derinden etki edebildiği tarih boyunca bilinen pandemiler ve son pandemi olan Coronavirus pandemisi ile gerçekliği anlaşılmıştır.

Ulusal güvenliği gerek adli suçlardan gerek sağlık sorunların korumak için ülke sınırlarının hem emniyet güçleri hem sağlık çalışanları ile denetlenen geçişlerin sağlanması gerekmektedir. Yakın dönemde gerçekleşen Irak ve Suriye kitlesel göçleri ile Çin'den gelen Coronavirus hastalığı bu önerinin ekseriyetle uygulanması gerekliliğini gözler önüne sermiştir. Bu olgular, Dünya üzerinde en fazla Suriyeli nüfusuna sahip olan Türkiye dahil göçlerden etkilenen devletleri her yönden etkilediği ve uluslararası anlaşmalar gereği Avrupa tarafindan desteklenmesi gerektiği ortaya çıkmaktadır. Bu destek kalemleri ise sırasıyla bağışıklama ve aşılama çalışmaları, ilaç (antibiyotik vb.) ve sağlık hizmetleri alımı, temiz suya erişim, barınma ve beslenme, temiz suya erişim, 
sanitasyon sağlama, etkin ve düzenli sağlık sistemleri olarak devletlerin sağl1k sistemlerinin çökmesini önleyerek tüm dünyayı riske atabilecek olası bir bulaşıcı hastalıklar pandemisinide önleyecektir.

Günümüzde küresel areayı etkileyen en önemli ortak sorunlardan olan düzensiz göç konusunun yerini artık coronavirüs pandemisi almıştır. Dünya üzerindeki hemen tüm toplumların gerek göç gerekse salgın hastalıklar olsun pek çok problemin antropolojik ve sosyolojik açıdan incelenmesi gereklidir. Göç konusunun yalnızca ulusal değil uluslararası çözüme ulaşması gerektiği gibi salgın hastalıklarında uluslararası çözümlerle çözüme ulaştırılabileceği görüşündeyiz. Bu nedenle tüm süreç boyunca başta tüm sağlık personelinin, devlet büyüklerinin, hukukçuların, akademisyenlerin, kolluk güçlerinin, göç uzmanlarının, adli bilimcilerin ve antropologların ortak işbirliği halinde çalışması ve uygulamalara yön vermesi kalıcı çözüme ulaştıracaktır.

\section{Kaynakça}

Acar, A., Beşirbellioğlu, B. (2005). Kuş Gribi (Avıan Influenza). TSK Koruyucu Hekimlik Bülteni, 2005: 4 (6), 345-353.

AFAD, (2013). Türkiye'deki Suriyeli Sığınmacılar, 2013 Saha Araştırması Sonuçları. Afet ve Acil Durum Yönetimi Başkanlığg Yayınları, Türkiye Cumhuriyeti Başbakanlık.

AFAD, (2014). Suriyeli Misafirlerimiz Kardeş Topraklarında. Afet ve Acil Durum Yönetimi Başkanlı̆̆ $\quad$ Yayınlarl, Türkiye Cumhuriyeti Başbakanlık, https://www.afad.gov.tr/kurumlar/afad.gov.tr/17947/xfiles/syrian-refugees-in-turkey2013_baski_30_12_2013_tr_1_.pdf .

AFAD, (2018). Geçici Barınma Merkezleri Raporu. Afet ve Acil Durum Yönetimi Başkanlı̆̆ Yayınlart. https://www.afad.gov.tr/barinma-merkezlerinde-son-durum

Akşit, N. (1984). A'dan Z'ye Tarih Ansiklopedisi. Serhat Yayıncılık.

Ata, N. (2013). Göçle İlişskili Başlıca Paraziter Enfeksiyonlar. EKMUD Yayınları,

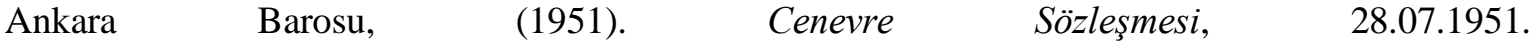
http://www.ankarabarosu.org.tr/siteler/ankarabarosu/tekmakale/2014-1/12.pdf

Arkeofili (2019, Nisan 09). Büyük Atina Vebası Demokrasinin Çöküşünü Hazırladı. https://arkeofili.com/buyuk-atina-vebasi-demokrasinin-cokusunu-hazirladi/

Aydoğan S, Metintas S. (2017). Türkiye’ye Gelen Dlş Göç ve Sağlı̆̆a Etkileri. Türk Dünyas1 Uygulama ve Araştırma Merkezi Halk Sağlığı Dergisi. 2(2), 37-45.

CDC (2020,Ocak 24). Whats's poliovirus? https://www.cdc.gov/polio/what-is-polio/index.htm

Centers for Disease Control and Prevention (CDC). (1998). First 500,000 AIDS cases United States 1995. MMWR Published. https://www.cdc.gov/mmwr/preview/mmwrhtml/00039622.htm.

Centers for Disease Control and Prevention (CDC). (2016). Tuberculosis Data and Statistics. MMWR Published. https://www.cdc.gov/tb/statistics/default.htm

Çalık R, Tepekaya M. (2006). Birinci Dünya Savaşı Esnasında Anadolu'daki Salgın Hastalıklar ve Ermeniler. Selçuk Üniversitesi Sosyal Bilimler Enstitüsü Dergisi, 16, 205-228.

Doğruyol S. (2007). Göç ve Bulaşıcı Hastalıklar. 1st Disaster and Pre-Hospital Management in the Middle East Congress Atuder. 
Eskiocak M, Marangoz B, Etiler N. (2016). Suriye, Türkiye ve Irak'ta Savaşın Bölgedeki Bulaşıcı Hastalıklara Etkileri. Ergin I. (Editör). Savaş, Göç ve Sağlık: Türk Tabipleri Birliği Yayınları. sayı: 978-605-9665-01-8. http://www.ttb.org.tr/kutuphane/siginmacilar_rpr.pdf.

Eskiocak M, Saltık A. (2018). Bağı̧ıılklama Hizmetlerinin Temel Bileşenleri. Relief Web STED. 1997; 6(11). https://reliefweb.int/report/syrian-arab-republic/syria-cvdpv2outbreaksituation-report-37-13-march-2018.

Ergönül, Ö. (2016). Enfeksiyon Hastalıkları Epidemiyolojisi. Okmeydanı Tıp Dergisi,32(Ek say1):17, doi:10.5222/otd.2016.001

Gölçek, G.Ş. (2019). Nükleer Silahların Adil Savaş Kuramındaki Yeri: Hiroşima ve Nagazaki Deneyimleri. FSCONGRESS 2019-2 Fiscaoeconomia Internatıonal Congress On Social Sciences.

Hussain H, Akhtar S, Nanan D. (2003). Prevalence of and risk factors associated with Mycobacterium tuberculosis infection in prisoners. North West Frontier Province, Pakistan, Int J Epidemiol ;32:794-99.

Joint United Nations Programme on HIV/AIDS (UNAIDS). (2018). Global HIV \& AIDS statistics - 2018 Fact Sheet. http://www.unaids.org/en/resources/fact-sheet.

Kılıç O. (2004). Genel hatlarılla dünyada ve Osmanlı devletinde salgın hastalıklar. Fırat Üniversitesi Rektörlüğü Orta Doğu Araştırmaları Merkezi Yayınları, No:6, Tarih Şubesi Yayınları No:5, Elazığ.

Kırık M., A. Özkoçak, V. (2020). Yeni Dünya Düzeni Bağlamında Sosyal Medya ve Yeni Koronavirüs (Covıd-19) Pandemisi. Akademik Sosyal Araştırmalar Dergisi, Y1l: 7, Sayı: 45, Nisan 2020, 133-154.

Klimud (t.y.). Grip. https://www.klimud.org/public/uploads/files/domuz_gribi_bilgilendirme.pdf

Klaus S.N., Frankenbur, S., Ingber, A. (1999). Epidemiology of cutaneous leishmaniasis. Clin Dermatol. Say1 17: 257-60.

Lugo, M. J. M. (2020 Nisan 16). COVID-19 in Post-Truth Societies, https://www.caracaschronicles.com/2020/04/16/covid-19-in-post-truth-societies

Medicalpark (2020). Kolera nedir? https://www.medicalpark.com.tr/kolera-nedir/hg-1850

Meuleau, M. (1978). Bordaş/ Laffont Dünya Tarihi Ansiklopedisi Antik Çağ. Cilt 2, Yener Yayınevi İstanbul.

München Saur, K.G. (1994). Encyclopedia of world problems and human potantial. Vol 1: World problems-Organization descriptions. 31 st edition, 1994/95. ISBN. 3-598-22221-1, New Providence.

National AIDS Trust. (2018). About world AIDS day. http://www.worldaidsday. org/about

Özkoçak, V. (2018). Antropometrıc Technıques Used For Determınıng Aesthetıc Anatomıcal And Anthropological Structure. Eurasian Academy of Sciences Eurasian Art \& Humanities Journal Volume:9 S:30- 38.

Özkoçak, V., \& Özdemir, F. (2018). Age-Related Changes in The External Noses Of The Anatolian Men. Aesthetic Plastic Surgery, 42(5), 1336-1342.

Özkoçak, V.,Koç,F., Gültekin,T. (2020). Pandemilere Antropolojik Baklş: Koronavirüs (Covid-19) Örneği. Turkish Studies, eISSN: 1308-2140. https://www.researchgate.net/profile/Vahdet_Oezkocak/publication/341327472_Turkish_S 
tudies_Pandemilere_Antropolojik_Bakis_Koronavirus_Covid-

19_Ornegi_Anthropological_Overview_of_Pandemics_Coronavirus_Covid-

19_Example/links/5ebb345ea6fdcc90d67228e6/Turkish-Studies-Pandemilere-

Antropolojik-Bakis-Koronavirues-Covid-19-Oernegi-Anthropological-Overview-of-

Pandemics-Coronavirus-Covid-19-Example.pdf

Ponting, C. (2000). Dünyanın Yeşil Tarihi- Çevre ve Büyük Uygarlıkların Çöküşü. A. Başc1-Sander (Çev.). Sabancı Üniversitesi Yayınları.

Sezen, İ., Turan, M., Kaya, A.A. (2018). Türkiye'deki Suriyeli Misafirler ve İlişkilendirilen Bulaşıcı Hastalıklar. Gümüşhane Üniversitesi Sağlık Bilimleri Dergisi, 7(4) 119- 127.

Sirman, Alp. (2020). Tarih Boyunca Salginlar ve Covid19. Popular Science Türkiye. Nisan 2020/04, Say1:96.

Surveillances, V. (2020). The Epidemiological Characteristics Of An Outbreak Of 2019 Novel Coronavirus Diseases (COVID-19). China, China CDC Weekly, 2(8), 113-122.

Sustainale Development Goals, UN (2020, May1s 05). Ensure Healthy Lives And Promote WellBeing For All At All Ages. https://www.un.org/sustainabledevelopment/health/

Spinney, L. (2017). Pale Rider: The Spanish Flu of 1918 and How It Changed the World. Public Afairs, ISBN: 978-1610397674.

T.C. İçişleri Bakanlığı Göç İdaresi Genel Müdürlügü (2018, Mayıs) Dünyada Göç. http://www.goc.gov.tr/files/files/5_y\%c4\%b11-kitapcik(1).pdf.

T.C. Sağlık Bakanlığı (2020, Ocak 20). Seyahat Să̆ğğ Rehberi. https://www.seyahatsagligi.gov.tr/Site/SaglikBilgisi/SYR

T.C. Sağlık Bakanlığı Ana Çocuk Sağlığı ve Aile Planlaması Genel Müdürlüğü. (2009). Cinsel Yolla Bulaşan Enfeksiyonlar (CYBE/HIV/AIDS). Sağlık Bakanlığı Yayın.

T.C. Sağlık Bakanlığı Halk Sağlığı Genel Müdürlüğü Bulaşıcı Hastalıklar Dairesi Başkanlığı. HIVAIDS İstatistikleri. Sağlık Bakanlığı Yayın. https://hsgm.saglik.gov.tr/tr/bulasicihastaliklar/862-hivaids/1135-h\%C4\%B1v-aids-istatislik.html.

T.C. Sağlık Bakanlığı Halk Sağlığı Genel Müdürlüğü. (2013). HIV/AIDS tanı tedavi klavuzu, Ankara. Sağlık Bakanlığı Yayın No: 919. https://hsgm.saglik.gov.tr/depo/birimler/ Bulasicihastaliklar-db/hastaliklar/HIV-ADS/Tani-Tedavi_Rehberi/hiv_aids_tani_tedavi_ rehberi_2013.pdf.

T.C. Sağlık Bakanlığı Halk Sağlığı Genel Müdürlüğü. (2018). HIV/AIDS tanı kılavuzu. Ankara. Sağlık Bakanlığı Yayın https://hsgm.saglik.gov.tr/depo/birimler/Bulasici-hastaliklar db/hastaliklar/HIVADS/Tani_Klavuzu/HIV-AIDS_Tani_Klavuzu.pdf.

T.C. Sağlık Bakanlığı (2004). Bulaşıcı Hastalıkların İhbarı ve Bildirim Sistemi Standart Tanı, Sürveyans ve Laboratuvar Rehberi. Sağlık Bakanlığı Yayın. Ankara, 2004, S:34.

Taşkın, D., Özkoçak, V., Koç, F. (2019). Adli Bilimler Perspektifinden 2024 Dünya İnsani Programlarının Antropolojik Açıdan Değerlendirilmesi. IJOPEC Publication Current Debates in Social Sciences Vol. 30 December 2019.

Toraks Derneği (2020). 1918 Íspanyol Gribi salgını ve Biz https://www.toraks.org.tr/halk/News.aspx?detail=5787

U.S. Department of Health and Human Services. (2019). A Timeline of HIV and AIDS. https://www.hiv.gov/hiv-basics/overview/history/hiv-and-aids-timeline. 
UNAIDS. (2014). Fast-Track: ending the AIDS epidemic by 2030. http://www. unaids.org/sites/default/files/media_asset/JC2686_WAD2014report_en.pdf.

UNIADS. (2016). Political Declaration on HIV and AIDS: On the Fast Track to Accelerating the Fight against HIV and to Ending the AIDS Epidemic by 2030. http://www.unaids. org/sites/default/files/media_asset/2016-political-declaration-HIV-AIDS_en.pdf.

United Nations Population Fund (UNFPA) (2018). HIV and AIDS. https://www.unfpa. org/hiv-aids.

United Nations Population Fund (UNFPA) ve Joint United Nations Programme on HIV/AIDS (UNAIDS). (2017). HIV Prevention 2020 Road Map. https://www.unfpa.org/ publications/hiv-prevention-2020-road-map.

WHO (2020). $Q \& A$ on coronaviruses (COVID-19). https://www.who.int/emergencies/diseases/novel-coronavirus-2019/question-and-answershub/q-a-detail/q-a-coronaviruses

Tözün, M., Sözmen, K. M. (2014). Halk Sağlı̆̆ının Tarihsel Gelişimi ve Temel Kavramları. Smyrna T1p Dergisi, 58-62.

Yavuz, H. (2013). Tarımda Riskli Sağlık Davranışları ve İlişkili Faktörler. T.C. Harran Üniversitesi Sağlık Bilimleri Enstitüsü Halk Sağlığı ABD, Yüksek Lisans Tezi, Şanlurfa.

Yücel, B., Görmez, A. (2019). SARS-Corona Virüsüne Genel Bakış. Türkiye Teknoloji ve Uygulamalı Bilimler Dergisi, 2(1), 32-39.

Özdemir, H. (2005). Salgın Hastallklardan Ölümler 1914-1918. Ankara: Türk Tarih Kurumu Yayınları.

Yang, R., Anisimov, A. (2016). Yersinia pestis: Retrospective and Perspective. China: Advances in Experiment Medicine and Biology, Springer Science and Business Media Dordrecht Publisher.

Yanık, M. (2018). Biyopsikososyal Model ve Doğru Nefes Alip Verebilme. http://www.medaimyanikklinigi.com/biyopsikososyal-model-ve-dogru-nefes-alipverebilme/\#: :text=Hastal\%C4\%B1klar\%C4\%B1n\%20v\%C3\%BCcudumuzdaki\%20h\%C 3\%BCcrelerde\%20bir\%20bozulmadan,ve\%20fiziksel\%20uyar\%C4\%B1lara\%20oldu\%C4 $\% 9 \mathrm{Fu} \% 20 \mathrm{gibi}$

Çalışır, C.H. (2016). Göç ve Tüberküloz. Klimik Türk Klinik Mikrobiyoloji ve İnfeksiyon Hastalıkları Derneği, 10, 3-49.

T.C. Sağlık Bakanlığ1 (2015). https://www.saglik.gov.tr/TR,1281/cocuk-felci-destek-asilamacalismalari.html

T.C. Sağlık Bakanlığı Halk Sağlığı Genel Müdürlüğü. (2018). HIV/AIDS tanı kılavuzu. Ankara. Erişim adresi: https://hsgm.saglik.gov.tr/depo/birimler/Bulasici-hastaliklardb/hastaliklar/HIVADS/Tani_Klavuzu/HIV-AIDS_Tani_Klavuzu.pdf. Erişim Tarihi: 05.04.2020.

T.C. Sağlık Bakanlığı. 07. 06. 1996 tarihli ve 3403 sayılı Ulusal AIDS Komisyonu kuruluş onayı

United Nations Population Fund (UNFPA). HIV and AIDS. Erişim adresi: https://www.unfpa. org/hiv-aids. Erişim Tarihi: 06.06.2020

UNICEF (2014). https://www.unicef.org/turkey/bas\%C4\%B1nb\%C3\%BCltenleri/iraktaki$\% \mathrm{C} 3 \% \mathrm{~A} 7$ ocuk-felci-vakas\%C4\%B1n\%C4\%B1n-ard\%C4\%B1ndan-ilk-toplu a\%C5\%9F\%C4\%B1-kampanyas\%C4\%B1-ba\%C5\%9Flat\%C4\%B11d\%C4\%B1 